\title{
A POPULAÇÃO DO REINO DE ANGOLA DURANTE A ERA DO TRÁFICO DE ESCRAVOS: UM EXERCÍCIO DE ESTIMATIVA E INTERPRETAÇÃO \\ (C. 1700-1850)"
}

\author{
Contatos \\ Maximiliano M. Menz \\ Rua Hermínio Lemos, 455 \\ 01540-000 - São Paulo - São Paulo \\ maxmacmenz@hotmail.com \\ Gustavo Acioli Lopes \\ Rua Real da Torre, 825/1004 \\ 50610-000 - Recife - Pernambuco \\ gustavo.acioli@ufrpe.br
}

\author{
(1) Maximiliano M. Menz ${ }^{* *}$ \\ Universidade Federal de São Paulo \\ Guarulhos - São Paulo - Brasil \\ (1) Gustavo Acioli Lopes ${ }^{* * *}$ \\ Universidade Federal Rural de Pernambuco \\ Recife - Pernambuco - Brasil
}

\section{Resumo}

O artigo discute a evolução da população sob o domínio português na região que era chamada "Reino de Angola" pelas autoridades coloniais, desde o século XVIII à primeira metade do século XIX. Nosso objetivo foi responder a uma pergunta simples: a população sob o domínio português teria aumentado ou diminuído neste período? Para isto, analisamos e criticamos um número razoável de mapas de população e outros dados quantitativos como os dízimos e a contagem dos sobas. O resultado a que chegamos é que existem indícios de crescimento pelo alargamento da fronteira durante o século XVIII e que, entre o final do século XVIII e o início do XIX, ocorreu um colapso demográfico que parece estar associado às secas e ao aumento da pressão escravizadora.

\section{Palavras-chave}

População-tráfico deescravos-Angola-Império português-Mapaspopulacionais.

* Pesquisa realizada com o apoio da Fundação de Amparo à Pesquisa do Estado de São Paulo - Fapesp. Os autores agradecem à professora Mariana P. Candido pelas críticas e sugestões, assim como aos pareceristas anônimos da Revista de História. Procuramos levar em consideração suas observações na redação da versão final deste artigo.

* Doutor pelo programa de pós-graduação em História Econômica do Departamento de História da Faculdade de Filosofia, Letras e Ciências Humanas da Universidade de São Paulo e professor do Departamento de História da Universidade Federal de São Paulo.

**t Doutor pelo programa de pós-graduação em História Econômica do Departamento de História da Faculdade de Filosofia, Letras e Ciências Humanas da Universidade de São Paulo e professor de História Econômica do Departamento de História da Universidade Federal Rural de Pernambuco - UFRPE. 


\title{
THE POPULATION OF
}

THE KINGDOM OF

ANGOLA DURING

THE SLAVE TRADE

ERA: AN EXERCISE IN

ASSESSMENT AND

ANALYSIS (C. 1700-1850)

\author{
Contacts \\ Maximiliano M. Menz \\ Rua Hermínio Lemos, 455 \\ 01540-000 - São Paulo - São Paulo \\ maxmacmenz@hotmail.com \\ Gustavo Acioli Lopes \\ Rua Real da Torre, 825/1004 \\ 50610-000 - Recife - Pernambuco \\ gustavo.acioli@ufrpe.br
}

\section{- Maximiliano M. Menz}

Universidade Federal de São Paulo

Guarulhos - São Paulo - Brazil

\section{- Gustavo Acioli Lopes}

Universidade Federal Rural de Pernambuco

Recife - Pernambuco - Brazil

\section{Abstract}

The article discusses the dynamics of the population under Portuguese rule in the region called "Kingdom of Angola" by the colonial authorities through the eighteenth century up to the first half of the nineteenth century. We aim answer a simple question: the population under Portuguese rule would have increased or decreased in this period? In order to do so, we analyze and criticize a sizable number of population maps and other quantitative data such as tithes and the numeration of "sobas". We find out that there are signs of growth, by the expansion of the Angola's border during the eighteenth century and that between the late eighteenth and early nineteenth occurred a demographic collapse that appears to be linked to droughts and an increasing enslaving pressure.

\section{Keywords}

Population - slave trade - Angola - Portuguese empire - population charts. 
O campo historiográfico sobre o tráfico escravista na e a partir da África atlântica é eivado de debates e polêmicas as mais diversas. Entre estas, uma das mais recorrentes diz respeito aos efeitos - sociais, econômicos, políticos, culturais - que a escravização e exportação de homens, mulheres e crianças na condição de escravos tiveram sobre as sociedades envolvidas no tráfico escravista. ${ }^{1}$ Dentro deste recorte, especialistas têm discutido o impacto demográfico que a contínua e crescente subtração de indivíduos - a grande maioria, homens jovens - de suas sociedades pelo comércio escravista acarretou. Pode-se afirmar, como o faz David Eltis, que a questão do impacto demográfico é que tem "espreitado" por trás de todos aqueles debates. ${ }^{2}$ Os argumentos são diversos, mas podem ser distinguidos entre os que apontam para a redução populacional nas áreas em que o envolvimento com o tráfico atlântico escravista foi intenso e aqueles que não consideram que houve redução demográfica significativa que possa ser atribuída ao comércio escravista.

Deve-se ter em conta, primeiramente, que a abordagem deste tema não considera apenas o fluxo quantitativo de pessoas escravizadas - o "numbers game $^{\prime \prime 3}$ - como variável a ser considerada na avaliação do impacto demográfico de tráfico escravista. O embarque de escravos nos portos da África atlântica - da Senegâmbia a Angola - rumo à América tinha por trás de si os mecanismos de "produção" de cativos, que incluíam guerras, raptos, razias, mas também o comércio e as trocas, nem sempre de caráter mercantil. ${ }^{4}$

Devido à complexidade do tema, estudos mais recentes têm enfatizado os aspectos e fontes qualitativas na abordagem das relações entre europeus e africanos (incluindo os descendentes de uniões entre estes). Assim, apontam para alguns limites dos dados numéricos como fundamento de análise dos efeitos do comércio de exportação de pessoas para as sociedades africanas..$^{5}$ Além disso, destacam outros aspectos, tais como a agência de africanos

\footnotetext{
1 Ver as sínteses de LOVEJOY, Paul. The impact of the Atlantic slave trade on Africa: a review of the literature. The Journal of African History, vol. 30, n. 3, nov. 1989, p. 365-94; MANNING, Patrick. Escravidão e mudança social na África. Novos Estudos, n. 21, jul. 1988, p. 8-29.

2 ELTIS, David. Economic growth and the ending of the transatlantic slave trade. Nova York: Oxford University Press, 1987, p. 64.

${ }^{3}$ M'BOKOLO, Elikia. África negra: história e civilizações, vol. 1: O século XVIII. Lisboa: Colibri, 2007, p. 325.

4 LOVEJOY, Paul. A escravidão na África: uma história de suas transformações. Rio de Janeiro: Civilização Brasileira, 2002, p. 32-34, 45, 63-5 et passim. MANNING, Patrick. Slavery and African life. Occidental, Oriental and African slave trade. Cambridge: CUP, 1995, p. 88-90.

${ }^{5}$ Ver GREEN, Toby. The rise of the trans-atlantic slave trade in Western Africa, 1300-1589. Nova York: Cambridge University Press, 2012; CANDIDO, Mariana P. An African slaving port and the Atlantic world: Benguela and its hinterland. Nova York: Cambridge University Press, 2013.
} 
no tráfico, o processo de crioulização e/ou de dessocialização dos indivíduos escravizados ${ }^{6}$ a fragilidade da condição dos indivíduos livres em áreas de incidência do comércio escravista, bem como aquilo que os números, às vezes, mais encobrem que revelam sobre os povos africanos engolfados pelo trato escravista atlântico. ${ }^{7}$

Por outro lado, entre os/as autores/as que têm abordado os aspectos quantitativos da demografia, deve-se distinguir, de forma geral, dois grupos: os que apontam o impacto demográfico negativo no curto prazo e em áreas específicas e aqueles que elaboraram modelos e argumentos que indicam tais efeitos no longo prazo. O mesmo se observa quanto aos que refutam tal impacto no longo prazo, ainda que não o neguem no curto prazo. Diante da constatação, afirmada por Walter Rodney e referida por Joseph Inikori e Stanley Engerman, de que a África foi o único continente a ter reduzida sua participação relativa na população global entre os séculos XVI e XX, consideramos que vale a pena insistir no tema. ${ }^{8}$

No referido debate, podemos tomar como ponto de partida dois autores que representam posições antagônicas: Walter Rodney e John Fage. Rodney considerava que a estagnação do crescimento demográfico do continente africano deveria ser atribuída ao tráfico de escravos. ${ }^{9}$ Por sua vez, Fage argumentou que as condições naturais adversas (clima e doenças) e uma agricultura ineficiente dificultavam o estabelecimento de "sociedades humanas prósperas e seguras", redundando na valorização dos "escassos recursos humanos" pelas autoridades locais e, portanto, os escravos vendidos pelos africanos aos europeus seriam os "rejeitos do sistema africano".10

\footnotetext{
6 SPARKS, Randy. Where the negroes are masters. An African port in the era of the slave trade. Cambridge, MA: Harvard University Press, 2014; SMALLWOOD, Stephanie E. Saltwater slavery: a middle passage from Africa to American diaspora. Cambridge, MA: Harvard University Press, 2007.

7 SILVA, Filipa Ribeiro da $\&$ SOMMERDYK, Stacey. Re-examining the geography and merchants of the West Central African slave trade: looking behind the numbers. African Economic History, vol. 38, 2010, p. 77-105; HALL, Gwendolyn Midlo. Slavery and African ethnicities in the Americas: restoring the links. Chapel Hill: University of North Carolina Press, 2005, p. 80-8. Parte das críticas tem sido direcionada às conclusões derivadas da base de dados Transatlantic slave trade. Sobre esta, ver o capítulo de seus organizadores: ELTIS, David \& RICHARDSON, David (ed.). A new assessment of the transatlantic slave trade. In: Idem. Extending the frontiers: essays in the new transatlantic slave trade. Yale, CT: Yale University Press, 2008, p. 1-60.

8 RODNEY, Walter. How Europe underdeveloped Africa. Londres: Bogle L'Ouverture, 1972, p. 97.

9 RODNEY, Walter. How Europe underdeveloped Africa, op. cit., p. 97-8.

${ }^{10}$ FAGE, John. African societies and the Atlantic slave trade. Past and Present, vol. 125, n. 1, 1989, p. 111-115. Citações nas p. 111 e 115.
} 
No entanto, estas são abordagens que, embora recorrendo a informações e dados de diversas áreas da África atlântica, tomam-na como um todo, sem distinguir áreas específicas ou demonstrar se houve ou não decréscimo demográfico em algumas delas. ${ }^{11}$ Podemos nos ater aos estudos mais específicos, que procuram discutir a questão com elementos oriundos da incidência do tráfico em determinadas áreas, como é o caso da historiografia que aborda o tema em relação às áreas habitadas pelos povos de língua Banto.

A África ocidental e a centro-ocidental foram as duas regiões mais intensamente envolvidas no fornecimento de cativos ao tráfico transatlântico de escravos do século XVI ao XIX. Embora a aquisição pelos europeus de trabalhadores africanos forçados tenha começado na Senegâmbia em fins do século XV, ${ }^{12}$ ao longo do século XVI deu-se uma inflexão para as áreas subequatoriais, ou seja, para Congo e Angola. Em poucas décadas, a presença e penetração portuguesa no reino do Ndongo faria de Luanda o maior porto escravista da África.

A atuação dos portugueses no tráfico de escravos na África centro-ocidental apresenta a peculiaridade, quando comparada à dos demais escravistas europeus, de contar com uma efetiva e crescente ocupação territorial e, assim, uma significativa presença de súditos portugueses (sejam os vindos do reino, sejam os luso-brasileiros ou luso-africanos). Enquanto ingleses, franceses e holandeses construíram dezenas de fortes no litoral da África ocidental ${ }^{13}$ sem, contudo, lograrem estabelecer-se no interior da Senegâmbia ou da Costa dos Escravos (Costa da Mina para os portugueses), os portugueses, a partir do momento que suas relações com o soberano do Congo começaram a tornar-se conflituosas, ${ }^{14}$ dirigiram-se para a conquista do reino

\footnotetext{
${ }^{11}$ Ver também os comentários gerais de THORNTON, John. A África e os africanos na formação do mundo atlântico: 1400-1800. Rio de Janeiro: Campus, 2004, p. 121-4, que sustentam a posição de Fage; e, no sentido contrário, os de LOVEJOY, Paul. The impact of the Atlantic slave trade on Africa, op. cit., p. 387-8.

12 RODNEY, Walter. A history of the upper Guinea coast, 1545-1800. Nova York: Monthly Review, 1970, p. 74; GREEN, Toby. The rise of the trans-Atlantic slave trade in Western Africa, 1300-1589. Nova York: Cambridge University Press, 2012, p. 69-80.

${ }^{15}$ ELTIS, David. The rise of African slavery in the Americas. Cambridge: Cambridge University Press, 2000, p. 174.

${ }^{14}$ Com severos efeitos sobre a população do reino, cf. HEYWOOD, Linda. Slavery and its transformations in the Kingdom of Kongo: 1491-1800. The Journal of African History, n. 50, 2009, p. 1-22. Ver também as narrativas clássicas sobre o tema de Ralph Delgado (especialmente os primeiros dois volumes): DELGADO, Ralph. História de Angola. 4 volumes. Benguela/Lobito: Edições do Banco de Angola, 1948-1955. BIRMGHAM, David. Trade and conflict in Angola. The Mbundu and their neighbours under the influence of the Portuguese 1483-1790. Oxford: Clarendon Press, 1966 e VANSINA, Jan. Kingdoms of the Savanna. Madisson: University of Wisconsin Press, 1966. Também devem ser consultados os trabalhos mais recentes de THORNTON, John.
} 
do Ndongo onde, não sem resistência do soberano e de outras autoridades políticas da região, acabariam por fincar um domínio territorial efetivo, ainda que nunca tenha correspondido plenamente à jurisdição nominal que o rei de Portugal afirmava ter em Angola. ${ }^{15}$

O estabelecimento dos portugueses nesta região e sua penetração pelo interior a partir de meados do século XVI, submetendo sobas à suserania portuguesa, pode ser atestado pelo fato de construírem fortificações ("presídios") em várias localidades, sendo a primeira em Massangano (1583), para estabelecer maior vigilância e controle sobre as "feiras" e rotas nas quais os escravos eram adquiridos e por onde eram levados rumo ao litoral. ${ }^{16}$

Devido à amplitude e densidade de sua pesquisa, um dos trabalhos mais influentes é o de Joseph Miller sobre Angola. ${ }^{17}$ No que diz respeito ao impacto demográfico do tráfico escravista sobre as populações de Congo e Angola, podemos sumarizar o argumento de Miller da seguinte forma: as regiões habitadas pelos povos bantos eram sujeitas a secas periódicas, havendo áreas reduzidas onde a fertilidade da terra e a pluviometria podiam sustentar uma população densa. De acordo com um modelo "neomaltusiano", o aumento da densidade populacional nas áreas mais úmidas levava ao deslocamento de parte da população para as terras marginais, que não po-

Early Kongo Portuguese relations: a new interpretation. History in Africa, vol. 8, 1981, p. 183204 e GONÇALVES, Antônio. A história revistada do Kongo e de Angola. Lisboa: Estampa, 2005.

${ }^{15}$ BIRMINGHAM, David. Trade and conflict in Angola. Oxford: Claredon Press, 1966, p. 54. HEINTZE, Beatrix. A política econômica e de colonização portuguesa em Angola de 1570 a 1607. In: Idem. Angola nos séculos XVI e XVII. Luanda: Kilombelombe, 2007, p. 258. MILLER, Joseph C. The numbers, origins, and destinations of slaves in the eighteenth-century Angolan slave trade. In: INIKORI, Joseph \& ENGERMAN, Stanley (ed.). The Atlantic slave trade: efects on economies, societies and peoples in Africa, the Americas and Europe. Durham, Londres: Duke University Press, 1992, p. 77-116; LOPES, Gustavo Acioli \& MENZ, Maximiliano M. Resgate e mercadorias: uma análise comparada do tráfico luso-brasileiro em Angola e na Costa da Mina (século XVIII). Afro-Ásia, no 37, 2008.

${ }^{16}$ BIRMINGHAM, David. Trade and conflict in Angola, op. cit., p. 54. HENRIQUES, Isabel de Castro. A organização afro-portuguesa do tráfico de escravos (séculos XVII-XIX). In: HENRIQUES, I. de C. \& MEDINA, João. A rota dos escravos. Lisboa: Segia, 1996, p. 239-40. A evolução do domínio territorial português pode ser constatada em diversas relações de fortalezas e de soldados que existem na documentação: FONSECA, André Velho da. Relatório de todos os gastos que se fazem nos reinos de Angola e de Congo, assim de justiça e governo como da igreja e guerra (1612). Arquivos de Angola, vol. III, fl. 19-21, abril a junho de 1937; SILVA, Luís Lobo; SOUZA, João da Silva de; CABRAL, Hierônimo da Veiga. Relação por maior do estado em que acha o Reino de Angola, suas províncias e conquistas, do número de gente de guerra e moradores e residentes desta cidade e seus presídios (...), 20/11/1684. AHU, Avulsos, Angola, cx. 13, doc. 1575. Ver também os documentos citados na análise demográfica.

${ }^{17}$ MILLER, Joseph C. Way of death. Merchant capitalism and the Angolan slave trade, 1780-1830. Madison, Wisconsin: University of Wisconsin, 1988. 
deriam sustentar o crescimento da população em períodos de estiagem e de seca, ${ }^{18}$ levando à oscilação periódica da população. Portanto, os escravizados que acabavam nas mãos dos traficantes europeus no litoral provinham do excedente populacional que, de qualquer forma, teria morrido de fome ou de doenças se permanecesse no interior de Angola. ${ }^{19}$ Assim, conclui o autor, "the slave trade appears in some ways less a cause of depopulation than a consequence of it when viewed in terms of droughts and demographic changes in West-Central Africa". ${ }^{20}$

Vale notar aqui que a existência de ciclos agrários, caracterizados pela expansão demográfica e decorrente queda na produtividade marginal da agricultura, e os "ajustes malthusianos" - fomes, epidemias e alta mortalidade - estão bem documentados para largas zonas da África subsaariana. Os ciclos, contudo, não são exclusivos desta região do globo: movimentos demográficos análogos são conhecidos em muitas sociedades camponesas pré-industriais e a especificidade africana, por assim dizer, seria a sua ligação com a expulsão sistemática de pessoas por meio do tráfico de escravos. ${ }^{21}$

Outro elemento elaborado por Miller correlacionado ao argumento da neutralidade demográfica do tráfico no longo prazo consiste na "fronteira de escravização". A partir do século XVI, a área varrida pelos métodos violentos de produção de cativos em Angola deslocou-se continuamente em ondas. A ocorrência de secas, conjugadas às epidemias e guerras (cuja deflagração relacionava-se diretamente à deterioração das condições socioeconômicas), diminuía a população no litoral, baixava o valor dos escravos, provocava êxodos e desestabilizava as autoridades tradicionais, esgotando as fontes locais de escravos. O avanço da "onda demográfica" deixava atrás de si instituições governadas por "príncipes mercadores", enquanto a violência era levada mais para o interior, onde "senhores da guerra" assumiam a liderança política e a produção de cativos. A "pacificação" das áreas mais próximas

\footnotetext{
${ }^{18}$ Ibidem, p. 150-1. MILLER, Joseph. The significance of drought, disease and famine in the agriculturally marginal zones of West-Central Africa. The Journal of African History, vol. 23, n. 1, jan. 1982, p. 22-28.

${ }^{19}$ MILLER, Joseph. The significance of drought, disease and famine, op. cit., p. 22-8; MILLER, Joseph. Way of death, op. cit., p. 153-6.

${ }^{20}$ MILLER, Joseph. The significance of drought, disease and famine, op. cit., p. 30.

${ }^{21}$ Cf. DIAS, Jill. Famine and disease in the history of Angola c. 1830-1930. The Journal of African History, n. 22, p. 349-378; WRIGLEY, Edward Anthony. Historia y poblacion: introducción a la demografia histórica. $2^{\text {a }}$ edição. Barcelona: Critica, 1985; LADURIE, Emmanuel Le Roy. História dos camponeses franceses. 2 volumes. Rio de Janeiro: Civilização Brasileira, 2007. Note-se que Jan de Vries questiona a validade do ciclo malthusiano para as crises sociais da Europa no século XVII; VRIES, Jan de. A economia da Europa numa época de crise. Lisboa: Dom Quixote, 1983, p. 36.
} 
ao litoral permitiria a recomposição de sua população, não mais sujeita às razias e guerras escravistas. ${ }^{22}$

Nesta mesma linha de argumentação, John Thornton, a partir de dados do último quarto do século XVIII, aponta que as alterações nos padrões demográficos de Angola, sobretudo a baixa taxa de masculinidade, não afetou o crescimento populacional de Angola no longo prazo, uma vez que as taxas de fertilidade e mortalidade não teriam sido alteradas significativamente, proporcionando um potencial de crescimento que contrabalançava as perdas de jovens adultos para o tráfico transatlântico de escravos. ${ }^{23} \mathrm{O}$ autor admite o despovoamento no curto prazo em áreas intensamente atingidas pela drenagem de pessoas por meio da exportação de escravos, mas considera que o impacto seria anulado pelo crescimento "normal" da população ao longo dos quarenta anos que se seguiram ao fim do tráfico; portanto, sem efeitos demográficos negativos no longo prazo. ${ }^{24}$

Comparando dados demográficos de fins do século XVIII, coligidos pelo governador de Benguela, Alexandre José Botelho de Vasconcelos, com outros produzidos em meados do século seguinte (a partir dos relatos do viajante húngaro Laszló Magyar), ${ }^{25}$ Thornton e Linda Heywood concluem pelo significativo crescimento populacional nos reinos ovimbundo no período 17991850. ${ }^{26}$ Depois de argumentarem sobre a confiabilidade dos dados das fontes, por serem de base fiscal e oriundos de informantes fiáveis, eles chegam a estimativas do total da população dos reinos ovimbundos em cada um daqueles anos, embora prefiram basear suas conclusões no número de aldeias reportadas pelas duas fontes, ainda que parte destes dados também sejam estimativas calculadas pelos autores. Quando o número específico de aldeias em algum dos quatro reinos ovimbundos não é dado por Magyar para 1850,

\footnotetext{
${ }^{22}$ MILLER, Joseph. Way of death, op. cit., p. 144-155. Em tese recente, Daniel Domingues da Silva questiona, com base em registros dos anos 1831-1855, que a maioria dos cativos deportados por Angola tenha vindo de áreas afastadas do interior, demonstrando que o maior contingente veio de áreas vizinhas a Luanda; cf. SILVA, Daniel Domingues da. The Atlantic slave trade from West Central Africa, 1780-1867. Nova York: Cambridge UP, 2017, p. 73-84.

${ }^{23}$ THORNTON, John. The slave trade in eighteenth century Angola: effects on demographic structures. Canadian Journal of African Studies, vol. 14, n. 3, 1980, p. 423-424.

${ }^{24}$ Ibidem, p. 425-6.

${ }^{25}$ Sobre este viajante, ver SEBESTYÉN, Éva. A sociedade ovimbundu nos relatórios de viagens do húngaro László Magyar: sul de Angola, meados do século XIX. Revista História: Debates e Tendências, vol. 15, n. 1, 2015, p. 83-100.

${ }^{26}$ HEYWOOD, Linda $\&$ THORNTON, John. African fiscal systems as sources for demographic history: the case of Central Angola, 1799-1920. The Journal of African History, vol. 29, n. 2, 1988, p. 223-4.
} 
eles as estimaram dividindo a população relatada para Wambu por 195 (média entre a população mínima e máxima das vilas deste reino registrada por Botelho de Vasconcelos) ou por 120 para Mbailundu (média das estimativas de Magyar). O estudo de Thornton e Heywood, contudo, trata majoritariamente de populações que não estavam avassaladas às autoridades portuguesas e o seu marco temporal não cobre importantes inflexões demográficas que podem ser verificadas para o Reino de Angola entre 1770 e $1850 .{ }^{27}$

Uma análise mais embasada em fontes, mas restrita à população de Luanda, foi elaborada por Curto e Gervais. Neste artigo, os autores apresentam uma ampla coleção de estatísticas populacionais, nada menos do que 29, discutindo o contexto político de sua produção, organizando os dados em categorias de sexo, grupos etários, cor etc. Sua conclusão principal é que houve uma redução "catastrófica" na população da capital do Reino de Angola entre 1781 e 1844 e que a sua principal causa foi a crescente demanda por escravos no Brasil e mais especificamente no Rio de Janeiro. Em outro artigo que é um desdobramento do texto referido, Curto interpretou o forte crescimento populacional ocorrido em Luanda entre 1844 e 1866 como o resultado da abolição do tráfico atlântico de escravos e decorrente desenvolvimento do "comércio legítimo". ${ }^{28}$

Mariana Candido também apresentou uma série com diversas contagens entre 1795 e 1850 para as populações do porto de Benguela e do presídio de Caconda, ao sul de Luanda. Notou uma estagnação demográfica no porto

\footnotetext{
${ }^{27}$ O número de vilas nos reinos de Wambu e Mbailundu em 1850 é derivado do total da população destes reinos fornecido por Magyar, dividido pelo número médio de habitantes por vila dado por Botelho de Vasconcelos (Wambu) ou pelo número médio estimado por Magyar (Mbailundu). HEYWOOD, Linda \& THORNTON, John. African fiscal systems, op. cit., p. 224-5, tabela 3. Além de concluírem que o tráfico transatlântico escravista não afetou o crescimento demográfico de Angola, os autores indicam que o seu encerramento em meados do século XIX teria contribuído para a intensificação do tráfico interno e, este sim, levado à redução populacional nas áreas do Império Lunda; Ibidem, p. 227. O aumento populacional de Luanda depois do fim do tráfico transatlântico é demonstrado e discutido em CURTO, José. The anatomy of a demographic explosion: Luanda, 1844-1850. The International Journal of African Historical Studies, vol. 32, n. 2/3, 1999, p. 381-405.

${ }^{28}$ CURTO, José \& GERVAIS, Raymond. A dinâmica demográfica de Luanda no contexto do tráfico de escravos do Atlântico Sul, 1781-1844. Topoi, n. 4, 2002, p. 85-138 e CURTO, José. The anatomy of a demographic explosion: Luanda, 1844-1850. The International Journal of African Historical Studies, vol. 32, n. 2/3, 1999, p. 381-405. Por sua vez, o impacto do tráfico na demografia do Rio de Janeiro, particularmente na organização das famílias, foi estudado por FLORENTINO, Manolo. The slave trade, colonial markets, and slave families in Rio de Janeiro, Brazil, ca. 1790-ca. 1830. In: ELTIS, David \& RICHARDSON, David. (ed.). Extending the frontiers. Essays on the new transatlantic slave trade database. New Haven: Yale University, 2008.
} 
sulino - cuja população era composta esmagadoramente por negros/as, entre os quais, a maioria escrava - durante todo o período. Considera que o comércio escravista explica mais sobre a dinâmica demográfica de Benguela que secas ou epidemias. Segundo a autora, "non cabe duda de que la esclavitud local en Benguela estaba intimamente relacionada con la trata de esclavos transatlántica". ${ }^{29}$

Processo similar deu-se no presídio interiorano, ainda que, em 1850, Caconda apresente um aumento significativo em sua população. A autora questiona a veracidade dos números globais para o presídio, tanto em relação a sua aparente imobilidade no início do século XIX, quanto pelo forte aumento apresentado na última contagem, mas produz ilações e análises a respeito da evolução das categorias parciais, como o número de escravos, que tendeu a aumentar no final do período, e a proporção de mulheres. Os habitantes de Caconda eram afetados tanto pelo comércio escravista quanto pelas razias promovidas pelos sobas não subordinados aos portugueses e pelas migrações internas, também relacionadas à dinâmica mercantil atlântica. ${ }^{30}$

Mais recentemente, Paulo Tedoro Matos e Jelmer Vos publicaram um artigo que apresenta uma primeira avaliação dos dados demográficos de Angola reunidos no âmbito do projeto Counting colonial populations. Organizando os dados demográficos produzidos nos presídios e distritos angolanos para os anos de 1800 e 1820 por categorias de idade, sexo etc., os autores compararam os seus resultados com as contagens gerais de 1777 e 1850. Sua preocupação, contudo, é principalmente com as relações laborais em Angola, sem avançar na análise da dinâmica demográfica dos domínios portugueses na África centro-ocidental. ${ }^{31}$

O artigo de Daniel Domingues da Silva também é fruto do projeto Counting colonial populations e elabora uma análise crítica de diversos mapas populacionais existentes entre o final do século XVIII e início do XIX. Apresenta, assim, a cobertura territorial, o conteúdo e as categorias utilizadas, a acuidade dos resultados e os métodos das contagens. Sua conclusão mais importante é que, apesar de pouco acurados, os mapas "fornecem uma ideia aproximada

\footnotetext{
${ }^{29}$ CANDIDO, Mariana. Fronteras de la esclavización: esclavitud, comercio, e identidad en Benguela, 1780-1850. México, D.F:: El Colegio de México, Centro de Estudios de Asia y África, 2011, p. 75-107. Citação à p. 98. ${ }^{30}$ CANDIDO, Mariana. Fronteras de la esclavización, op. cit., p. 115-153.

${ }^{31}$ MATOS, Paulo Teodoro de $\mathcal{E}$ VOS, Jelmer. Demografia e relações laborais em Angola, 1800: um ensaio metodológico. Diálogos - Revista do Departamento de História da Universidade Estadual de Maringá, vol. 17, n 3, 2013, p. 807-834.
} 
do tamanho e distribuição" da população de Angola sob o domínio português. $^{32}$

Apesar dessas contribuições mais recentes, o estudo de Thornton do final dos anos 1970 permanece como a referência mais abalizada e geral para o Reino de Angola. Afinal, ainda que se concentre em duas contagens dos anos de 1777 e 1778, o autor comprovou a alta concentração de mulheres em idade fértil entre as populações submetidas ao domínio lusitano e taxas de mortalidade e de natalidade relativamente "normais" para o período, o que permitiria sustentar a exportação constante de pessoas e ainda assim algum crescimento demográfico. Contudo, como já foi visto, as contagens de populações no Reino de Angola e os dados fiscais existente são mais numerosos e permitem análises mais fundamentadas empiricamente do que a elaborada pioneiramente por Thornton. ${ }^{33}$

Sendo assim, a proposta deste artigo é discutir a evolução da população sob o domínio português na região que era chamada "Reino de Angola" pelas autoridades coloniais entre o século XVIII e a primeira metade do século XIX ${ }^{34}$ Em síntese, pretende-se responder a uma pergunta bastante simples: a população sob o domínio português aumentou ou diminuiu neste período? Por isso, centramos nossa análise nos números totais.

O debate sobre a evolução demográfica das populações submetidas a Portugal na África está necessariamente relacionado com o impacto do tráfico. Entretanto, a resposta a esta pergunta não é simples, pois nossos dados são demográficos e políticos ao mesmo tempo. Os números registrados pelas

\footnotetext{
32 SILVA, Daniel Domingues da. The early population charts of Portuguese Angola, 1776-1830: a preliminary assessment. Anais de História do Além-Mar, vol. XVI, 2015, p. 121.

33 THORNTON, John. The slave trade in eighteenth century Angola, op. cit. A metodologia e os resultados de Thornton foram questionados por Jan Vansina: “cujo modelo [de Thornton] nos parece otimista demais (...). Ele admite uma diminuição da população, mas seu modelo subestima o número de mulheres (segundo ele, um quarto, e não um terço) e de crianças (segundo ele, nenhuma teria sido embarcada). Esses números são cruciais em matéria de demografia". VANSINA, Jan. O Reino do Congo e seus vizinhos. In: OGOT, Bethwell A (ed.). História geral da África, vol. V: África do século XVI ao XVIII. Brasília: Unesco, 2010, p. 667, nota 36; p. 692, nota 83.

${ }^{34}$ No final do século XVIII, a jurisdição portuguesa concentrava-se entre os rios Dande e Cuanza até Cassange e Matamba, incluindo-se os distritos ou presídios do Ikolo, Bengo, Dande, Golungo, Pedras de Pungo-a-Ndongo, Cambembe, Vila de Massangano, ao norte a fortaleza de Encoje e ao sul a vila de Benguela e de Caconda. O número de distritos sob jurisdição portuguesa (de fato ou nominalmente) era contado em 12 no início dos anos 1780, mas eram 15 cerca de quarenta anos depois; por outro lado, o número de presídios permaneceu inalterado; cf. SILVA, Daniel Domingues da. The early population charts of Portuguese Angola, 1776-1830, op. cit., p. 111-2. A lista de distritos e presídios contabilizados pode ser verificada no apêndice.
} 
autoridades portuguesas eram o resultado da variação do crescimento vegetativo das populações, das migrações, ampliação/diminuição da fronteira política e da própria percepção das autoridades do que seria este domínio. Os valores analisados aqui não representam, portanto, a "demografia real", mas uma "demografia política", problema generalizado para todas as fontes produzidas na época protoestatística, aliás, mas talvez mais presente nas situações coloniais. Ainda assim, através do controle e comparação entre as contagens gerais e parciais é possível apresentar algumas conclusões verossímeis. ${ }^{35}$

Para tanto, utilizamos séries pouco exploradas, mas também procuramos aprofundar a análise em conjunto de algumas contagens populacionais já bem conhecidas do público especializado, como o caso do censo de 1777, mapas de população para alguns distritos e outras duas contagens gerais publicadas durante o século XIX. Também incluímos alguns dados fiscais que permitem algumas aproximações ao movimento populacional.

Comecemos sistematizando os números que possuímos sobre o dízimo, imposto cobrado aos povos, teoricamente 10\% da produção agrícola, em troca do suposto pasto espiritual que deveria ser fornecido pelo Estado português às populações coloniais desde o padroado (1514). Existe uma série bastante completa entre 1717 e 1765. Seus valores em Angola, contudo, são difíceis de interpretar: tradicionalmente eram arrendados em duas partes, os da cidade de Luanda que eram cobrados aos proprietários de arimos, fazendas de policultura controladas pela população lusófona próximos da capital, e os referentes ao sertão que incidiam principalmente sobre a população avassalada dos sobados em torno dos distritos ao redor do Kwanza. Se pelos primeiros é provável que se pagasse uma parte da produção rural, pelos últimos a prática era os ramistas receberem uma pedra de sal de cada família (fogo) que valeria em torno de 80 mil réis na década de 1760, algumas varas de algodão e mais os "telecos", a hospedagem do dizimeiro nas terras dos so-

\footnotetext{
${ }^{35}$ Como escreveu David Landes: "Las fuentes cuantitativas del período protoestadístico son función tanto de las relaciones entre el Estado y la economia como de la filosofia y la técnica de los estadísticos". LANDES, David. Las estadísticas como fuente para la historia de Europa Ocidental. In: LORWIN, Val \& PRICE, Jacob (int.). Las dimensiones del pasado. Estudios de historia cuantitativa. Madri: Alianza Universidad, 1974, p. 20-21. Ver também as amplas considerações de Witold Kula sobre o tema, particularmente seu comentário sobre as populações que não eram registradas na Europa pré-industrial. KULA, Witold. Problemas y métodos de la história económica. $3^{\text {a }}$ edição. Madri: Ediciones Península, 1977, p. 342; e os argumentos de Braudel sobre a população chinesa. BRAUDEL, F. Civilização material, economia e capitalismo. As estruturas do cotidiano, vol. 1. São Paulo: Martins Fontes, 1997. Paulo Teodoro Matos e Jean Voss também realçam esse problema da fonte em seu artigo Demografia e relações laborais em Angola, op. cit.
} 
bas. Os lucros dos contratadores eram o resultado da diferença entre o valor cobrado no sertão e os pagamentos que faziam à Fazenda Real em Luanda. ${ }^{36}$ Ainda que os registros que possuímos a respeito dos mecanismos da cobrança afirmem que apenas uma parte da população teoricamente submetida era efetivamente taxada, o que importa é a tendência. A hipótese que exploramos aqui é que os dízimos do sertão, por serem uma taxa sobre os fogos, deveriam variar de acordo com a percepção dos dizimeiros sobre a quantidade de pessoas que poderiam ser taxadas; a variação deveria acompanhar o tamanho das populações do hinterland de Luanda, onde se concentravam os povos taxados. Obviamente que não existem elementos de prova para sustentar esta ideia, pois os dízimos eram leiloados pela provedoria de Angola e os valores que possuímos são apenas registros contábeis do que os contratadores deveriam pagar à Fazenda Real, enquanto que o que era efetivamente arrecadado pelos contratadores e ramistas do contrato perdese completamente pela ausência de fontes. Ademais, a leitura da correspondência dos governadores e o conhecimento dos mecanismos da arrecadação mostram que ocorreram mudanças nos ajustes com as populações locais para o pagamento dos dízimos, especialmente depois da década de 1760. Também pode ter variado o número de vassalos taxados com a sublevação ou incorporação de novas chefaturas; por último, os valores nominais registrados pela provedoria de Angola podem ter variado em razão das constantes manipulações da moeda provincial que ocorriam no domínio africano. ${ }^{37}$

\footnotetext{
${ }^{36}$ Francisco Inocêncio de Sousa Coutinho, 30/06/1765. AHU, Avulsos, Angola, cx. 49, doc. 37. Em 1804, a taxa era de 200 mil réis por fogo. As estratégias dos dizimeiros para ampliar a cobrança são relatadas em Francisco Antônio Pitta Bezerra d'Alpoim e Castro, posterior a 1796. AHU, Avulsos, Angola, cx. 77, doc. 85 (antiga). A resistência dos sobas consta em D. Fernando Antônio de Noronha, 01/01/1804. AHU, Avulsos, Angola, cx. 109, doc. 1.

37 Sobre os dízimos em Angola e suas formas de cobrança ver: Francisco Inocêncio de Souza Coutinho, 30/06/1765. AHU, Angola, Avulsos, cx. 49, doc. 37; Francisco Antonio Pitta Bezerra d'Alpoim de Castro, 1792. AHU, Angola, Avulsos, cx. 77, doc. 85; João Álvares de Motta, 25/02/1795. AHU, Angola, Avulsos, cx. 81, doc. 34. CORRÊA, Elias Alexandre. História de Angola, vol. 2, op. cit., p. 163-167. VENÂNCIO, José Carlos. A economia de Luanda e hinterland no século XVIII. Lisboa: Editorial Estampa, 1996, p. 90-93. Não temos séries dos valores dos dízimos depois de 1765, mas alguns números isolados sugerem que Corrêa claramente superestimou os valores que apresenta na p. 167. A historiografia econômica tem utilizado amplamente os dízimos para discutir as tendências da economia colonial no Brasil (ver, por exemplo, CARRARA, Ângelo Alves. Minas e currais. Produção rural e mercado interno de Minas Gerais, 1674-1807. Juiz de Fora: Editora da UFJF, 2007).
} 


\section{Gráfico 1: Dízimos do Reino de Angola, 1717-1765 (em réis)}

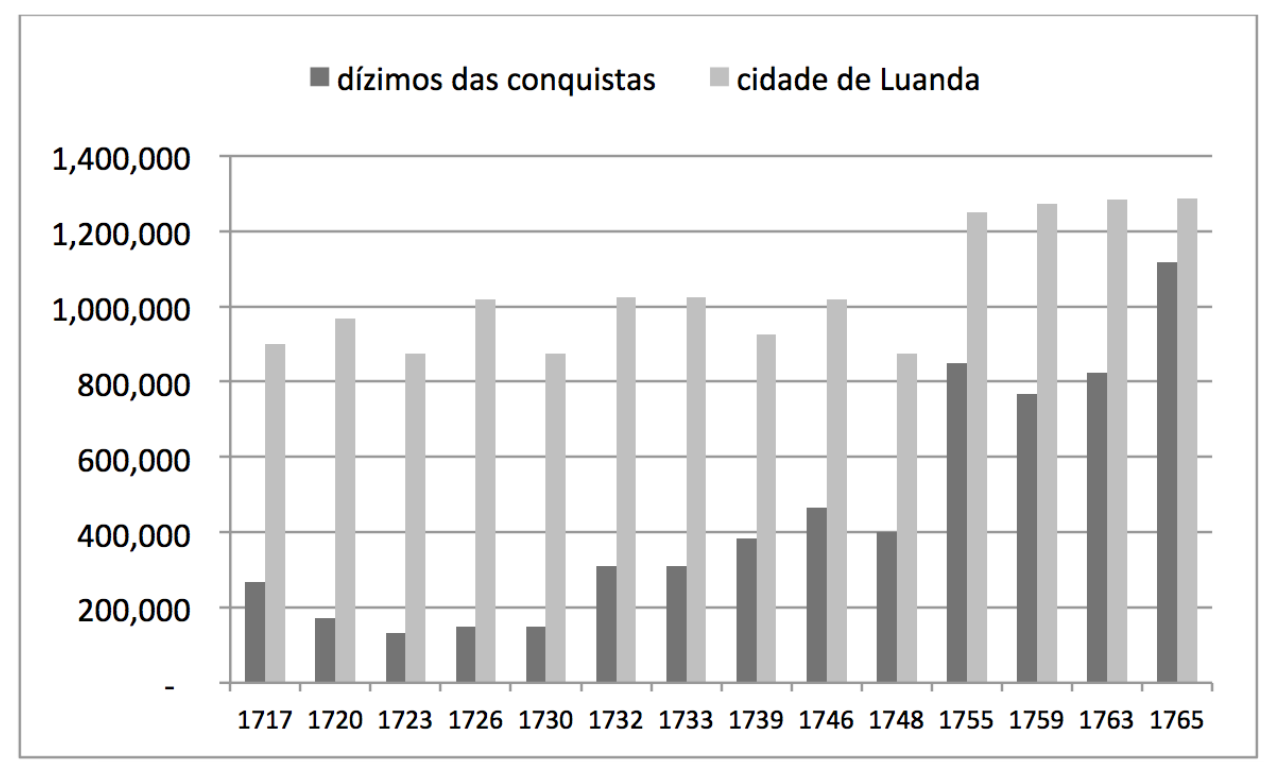

Fontes: Manuel Gomes de Avelar, 02/04/1731. AHU, Avulsos, Angola, cx. 28, doc. 2739; Manuel Gomes de Avelar, 07/04/1731. AHU, Avulsos, Angola, cx. 28, doc. 2745; Rodrigo César de Meneses, 30/07/1733. AHU, Avulsos, Angola, cx. 30, doc. 2895; Rodrigo César de Meneses, 30/08/1734. AHU, Avulsos, Angola, cx. 30, doc. 2951; 1739. AHU, Avulsos, Angola, cx. 34, doc. 3253; Fernando José da Cunha Pereira, 21/02/1750. AHU, Avulsos, Angola, cx. 40, doc. 3753; Fernando José da Cunha Pereira. AHU, Avulsos, Angola, cx. 39, doc. 3720; António Álvares da Cunha, 06/03/1756. AHU, Avulsos, Angola, cx. 43, doc. 4038; Antônio de Vasconcelos, 03/07/1760. AHU, Avulsos, Angola, cx. 43, doc. 52; Junta de Fazenda de Angola, 20/03/1760. AHU, Avulsos, Angola, cx. 48, doc. 5; Livro de Receita e Despesa da Fazenda Real do Reino de Angola do ano de 1765, AHTC_ER_4189, fl. 1. A reorganização dos documentos no AHU e o fato de termos recolhido a documentação no arquivo em duas ocasiões diferentes obrigam-nos a adotar uma classificação dupla para os avulsos de Angola: nos documentos até 1759 utilizamos a classificação nova, nos documentos entre 1760 e 1807 usamos a classificação antiga.

Em todo caso, na primeira metade do século XVIII, enquanto os métodos de arrecadação dos dízimos se mantiveram mais ou menos os mesmos, a tendência foi de um leve crescimento, principalmente nos do sertão que cresceram mais do que as arrematações de Luanda. A partir de 1765 ocorreram diversas mudanças nas formas de arrecadação, com a própria Fazenda Real fazendo-se cargo de cobrar os valores em alguns distritos. Também a divisão em duas consignações, "dízimos de Luanda" e "dízimos da conquista", foi alterada. Talvez por causa dessas alterações, entre 1780-1790, as cobranças cresceram bastante, chegando a valores superiores a 10 contos anuais; depois disso, a tendência parece ter sido novamente a estagnação, 
pois em 1819 valiam pouco mais de 15 contos e o dízimo do pescado 1,6 conto. Já em 1843-1844 constam no orçamento de Angola pouco mais de 17 contos nesta rubrica. ${ }^{38}$

A partir da série apresentada no gráfico 1, é possível arriscar que talvez a população do Reino de Angola tenha sofrido um leve incremento até o último quartel do século XVIII. Esta dedução, puramente especulativa, precisa ser confirmada por outros dados, ainda que não existam registros demográfico conhecidos antes de 1777.

Entretanto, entre os cálculos apresentados por Heywood e Thornton para Benguela consta uma estimativa de população a partir de uma lista de sobas e sobetes do final do século XVIII, utilizando um coeficiente para cada tipo de liderança. Para alguns presídios do interior é possível fazer algumas deduções parecidas, pois em 1684 foi enviada a Lisboa uma relação em que consta o número de sobas vassalos, quilombos (acampamentos militares) e jagas sob a proteção portuguesa em algumas dessas fortalezas. É um levantamento incompleto, mas por ele sabemos que Massangano, Cambembe, Pedras de Pungo-a-Ndongo, Ambaca e Calumbo teriam sob a sua jurisdição 129 sobas, 31 quilombos, e dois jagas. Duas contagens posteriores nas mesmas fortalezas apresentam uma variação pequena: 176 sobas no ano de 1797 e 203 sobas em 1810. A mudança mais expressiva ocorreu no presídio de Ambaca, onde o número de lideranças praticamente dobrou. ${ }^{39}$

Obviamente que é impossível saber se sobados, quilombos e jagas congregavam populações de grandezas similares, tampouco se houve uma mudança no número de pessoas que se reuniam em torno de uma liderança, mas a hipótese do crescimento durante o século XVIII é verossímil com as

\footnotetext{
${ }^{38}$ Até 1765 pelo menos, os dízimos eram divididos em "dízimos da cidade de Luanda" e "dízimos das conquistas"; pelos dados do Erário Régio, entre 1782-1788, estão discriminados os valores por distritos; em 1798 constam separados "dízimos do pescado" e "dízimos reais", com valores para os administrados pela Fazenda Real e os contratados. (Antonio Joseph Manzoni de Castro, 03/01/1799. AHU, Angola, Avulsos, cx. 91, doc. 71. AHTC, ER, cód. 4192). Os valores de 1843-1844 constam em LIMA, José Joaquim Lopes de. Ensaios sobre a statistica das possessões portuguezas no Ultramar, livro III, de Angola e Benguella e suas dependências. Lisboa: Imprensa Nacional, 1846, p. 187.

${ }^{39}$ Cf. HEYWOOD, Linda \& THORNTON, John. African fiscal systems, op. cit. Como argumenta Mariana Candido, os chefes que não estavam submetidos eram chamados de "jaga" pelas autoridades portuguesas. CANDIDO, Mariana. An African slaving port, op. cit., p. 55-61. O debate sobre o termo "jaga" é resumido pela autora e por PARREIRA, Antônio. Economia e sociedade em Angola. Na época da rainha Jinga. Lisboa: Editorial Estampa, 1990, p. 155-159. Cf., também, HEINTZE, Beatrix. As fontes da história pré-colonial de Angola ou a maravilhosa viagem dos jagas através dos séculos. In: Idem. Angola nos séculos XVI e XVII. Estudos sobre fontes, métodos e história. Luanda: Kilombembe, 2007, p. 25-66.
} 
duas aproximações que fizemos até aqui. Entretanto, é importante ressaltar que é pouco provável que a densidade populacional tenha aumentado nesse período, já que o crescimento das lideranças se concentrou no presídio de Ambaca, zona caracterizada por uma fronteira bastante móvel. Além disso, entre 1684 e os levantamentos populacionais do final do século XVIII, houve uma multiplicação no número de presídios e distritos contabilizados; assim, o crescimento dos dízimos pode ser o resultado da ampliação da fronteira do Reino de Angola. ${ }^{40}$

\section{Tabela 1}

Número de lideranças em alguns presídios de Angola

\begin{tabular}{|c|c|c|c|c|c|c|}
\hline \multirow{2}{*}{ Presídios } & \multicolumn{4}{|c|}{1684} & \multirow{2}{*}{$\begin{array}{c}1797 \\
\text { Sobas }\end{array}$} & \multirow{2}{*}{\begin{tabular}{|l}
1810 \\
Sobas
\end{tabular}} \\
\hline & Sobas & Quilombos & Jagas & Total & & \\
\hline Massangano & 13 & 14 & & 27 & 15 & 26 \\
\hline Cambambe & 21 & 8 & & 29 & 25 & 20 \\
\hline Pedras de Pungo Andongo & 49 & & & 49 & 35 & 37 \\
\hline Ambaca & 46 & 9 & 2 & 54 & 101 & 120 \\
\hline \multicolumn{2}{|l|}{ Total } & & & 159 & 176 & 203 \\
\hline
\end{tabular}

Fontes: para 1684, SILVA, Luís Lobo; SOUZA, João da Silva de; CABRAL, Hierônimo da Veiga. Relação por maior do Estado em que acha o Reino de Angola, suas províncias e conquistas, do número de gente de guerra e moradores e residentes desta cidade e seus presídios (...), 20/11/1684. AHU, Avulsos, Angola, cx. 13, doc. 1575. Demais dados foram retirados de AHU, CU, Angola, cx. 86, doc. 76; AHU, CU, Angola, cx. 122, doc. 21, de acordo com as planilhas de MATOS, Paulo et alli. Counting colonial populations. Disponível em: http://colonialpopulations.fcsh.unl.pt/. Acesso em: 14/04/2016.

Depois disto, temos o já bem conhecido censo de 1777 que contava 474.117 habitantes no Reino de Angola; o mapa não discrimina os distritos, nem registra se Benguela está incluída na contagem, constando apenas os totais organizados por sexo e a faixa etária. Este é um dos documentos analisados por Thornton que questionou os números agregados, já que o próprio governador que foi responsável por sua sistematização escreveu que os

\footnotetext{
40 Sobre Ambaca ver TORRES, João Carlos Feo. Memórias contendo a biographia do vice-almirante Luiz da Motta Feo e Torres, A história dos governadores e capitães gerais de Angola, desde 1575 até 1825 e a Descripção geographica e politica dos reinos de Angola e Benguela. Paris: Fantin Livreiro, 1825, p. 356-357.
} 
resultados eram duvidosos por causa da resistência dos sobas em revelar o número de seus súditos. Por esta crítica, pode-se presumir que a contagem teve um viés "baixista".

Por outro lado, Thornton aceitou seus valores relativos, daí as suas conclusões baseadas no alto número de mulheres e nas taxas de nascimentos e de mortes. Em outras palavras, o historiador americano acreditava que não foi contada toda a população, mas a parte que foi contada, foi contada bem. Entretanto, a comparação com as numerações de 1819 e 1845 sugere que a de 1777 incluiu o conjunto das populações avassaladas no Reino de Angola, incluindo as zonas ao sul em torno de Benguela e Caconda, além das pessoas submetidas na recém-criada fortaleza de Encoje ao norte. Não fosse assim, de onde sairiam contingentes populacionais tão expressivos? ${ }^{41}$

Já no início do século XIX, João Carlos Fêo Cardozo Torres publicou outros dados populacionais completos de Angola que teriam sido elaborados em 1819, discriminando exclusivamente as populações por distrito, sem maiores informações sobre idade, sexo ou condição civil, ainda que em alguns casos constem dados sobre o número de fogos e de escravos. Somando-se o Reino inteiro (Angola e Benguela), existiriam 358.437 pessoas sob o domínio português; teríamos, assim, uma redução populacional de $24 \%$. Os números apresentados por Torres carecem de precisão; dos 22 distritos, vilas e presídios apresentados apenas 12 estão discriminados às centenas, enquanto os demais parecem estimativas na casa dos milhares, do tipo "não menos do que 18 mil", como consta no distrito do Calumbo. Os números mais precisos concentram-se nos distritos em torno do rio Kwanza, onde a soberania portuguesa havia se consolidado ainda no século XVII; os números menos precisos constam entre os sobados avassalados no planalto de Benguela. ${ }^{42}$

Quase vinte anos depois, por volta de 1845, José Joaquim Lopes de Lima, responsável por produzir estatísticas sobre o Segundo Império português, copilou uma série de informações demográficas e fez o que ele chamou de um cálculo aproximado da população de Angola e Benguela, classificada por distritos, sexo e condição civil; o resultado desta contagem foi uma po-

\footnotetext{
${ }^{41}$ Antônio de Lencastre, 15/07/1778. AHU, Avulsos, Angola, cx. 61, doc. 81 (antiga). Ver também Miguel Antônio de Melo, 14/04/1800. AHU. Avulsos, Angola, cx. 95, doc. 42. Ver ainda a nota 19 e a extensa análise de THORNTON, John. The slave trade in eighteenth century Angola: Effects on demographic structures. Canadian Journal of African Studies / Revue Canadienne des Études Africaines, vol. 14, n. 3, 1980, p. 417-427 sobre este censo.

${ }^{42}$ TORRES, João C. F. Memórias contendo a biographia do vice-almirante Luiz da Motta Feo e Torres, op. cit., p. 352-375.
} 
pulação de 386.463 almas. Suas fontes foram os mapas remetidos "durante este século" por diversos governadores "em épocas diferentes", constando o número de fogos por distrito. Os números apresentados vão ao detalhe da unidade, mas a grande variação nas quantidades de habitantes por fogo permite suspeitar de tal precisão. ${ }^{43}$

Por último, houve uma contagem geral em 1866 que foi referida por Antônio Carreira, mas que não analisaremos aqui. Importa realçar apenas que, depois de 20 anos sem deportações, a população teria recuperado os números de 1777 , chegando a 473.860 pessoas. ${ }^{44}$

Em síntese, o que as contagens gerais mostram é uma redução severa entre 1777 e 1819, seguida de uma pequena recuperação na década de 1840, para finalmente haver um forte crescimento nos anos que se seguiram ao final do tráfico atlântico. Esta tendência parece encontrar respaldo nas alfândegas de Luanda, pois no período entre 1793 e 1819 exportou-se uma média de 20 mil escravos por ano, enquanto que, entre 1710 e 1792, foi deportada uma média de 12 mil indivíduos anuais. Depois de 1831, desaparecem os números oficiais, mas o abolicionismo teve algum impacto sobre o tráfico na região, concentrando o negócio nas mãos de grandes contrabandistas, deslocando as exportações para os portos ao norte de Luanda e, talvez, reduzindo a pressão do comércio de pessoas sobre as populações do Reino de Angola, o que explicaria a recuperação populacional na década de $1840 .{ }^{45}$

\footnotetext{
${ }^{43}$ LIMA, José Joaquim Lopes de. Ensaios sobre a statistica das possessões portuguezas no Ultramar, livro III, de Angola e Benguella e suas dependências. Lisboa: Imprensa Nacional, 1846. Curto afirma que o censo de Luanda foi feito em 1844, mas é pouco provável que os números de outras regiões possam ser datados com esta precisão. Tampouco as contagens anteriores (1777 e 1819) foram feitas em apenas um ano, como atesta a viagem de Francisco Antônio Pitta Bezerra d'Alpoim e Castro pelo Kwanza. Ver CURTO, José, The anatomy of a demographic explosion, op. cit., p. 385.

${ }^{44}$ CARREIRA, Antônio. Angola: da escravatura ao trabalho livre. Subsídios para a história demográfica do século XVI até a independência. Lisboa: Arcádia, 1977, p. 17.

45 TSTD, 2010. Sobre a abolição do tráfico em Angola e no Império português ver ALEXANDRE, Valentim. Portugal e a abolição do tráfico de escravos (1834-51). Análise Social, vol. XXVI, n. 111, $1991\left(2^{\circ}\right)$, p. 293-333; FERREIRA, Roquinaldo. The suppression of the slave trade and slave departures from Angola, 1830s-1860s. História Unisinos, vol. 15, n. 1, jan./abr. 2011, p. 3-13. Ver, ainda, BETHELL, Leslie. A abolição do tráfico de escravos no Brasil: a Grã-Bretanha, Brasil e a questão do tráfico de escravos, 1807-1869. Rio de Janeiro: Expressão e Cultura; São Paulo: Edusp, 1976, p. 94124, sobre os aspectos políticos e diplomáticos; e CONRAD, Robert. Tumbeiros: O tráfico escravista para o Brasil. São Paulo: Brasiliense, 1985; BERBEL, Márcia; MARQUESE, Rafael; PARRON, Tamis. Escravidão e política, Brasil e Cuba, 1790-1850. São Paulo: Hucitec, 2010; RODRIGUES, Jaime. O fim do tráfico transatlântico de escravos para o Brasil: paradigmas em questão. In: GRINBERG, Keila \& SALLES, Ricardo. O Brasil imperial, vol. II, 1831-1889. Rio de Janeiro: Civilização Brasileira, 2009, p. 299-337. A questão da abolição do tráfico escravista em Portugal é amplamente
} 
Entretanto, como o censo de 1777 não refere a extensão do território coberto, não é possível fazer conclusões peremptórias. Thornton, por exemplo, é da opinião de que o alto número de pessoas contabilizadas no século XVIII é sinal de que foram incluídos os reinos de Matamba e Kassange. Acreditamos que esta informação não é correta, pois há grande coerência entre os territórios considerados em 1819 e 1845 e em nenhum deles existe referência a estes dois reinos independentes. Em todo caso, não é possível descartar a possibilidade de que movimentos migratórios na zona Congo-Angolana tenham produzido essas mudanças demográficas.

Afortunadamente, temos pelo menos mais sete contagens que cobrem algumas zonas limitadas de Angola. A primeira delas é um levantamento feito pelo capitão de infantaria Francisco Antônio Pitta Bezerra d'Alpoim e Castro que visitou o interior de Angola, ao sul de Luanda, para acertar com as populações locais o pagamento dos dízimos; o mesmo apresentou no seu relatório uma contagem dos fogos e a distribuição das populações por sexo e faixa etária. Este assento foi feito entre os anos de 1792-1796, mas as contagens parecem ter ocorrido principalmente entre 1794 e $1796 .{ }^{46}$ A população registrada abrangeu os povos submetidos aos presídios de Ambaca, Pedras de Pungo Andongo, Cambambe, Muxima, Vila de Massangano e distrito de Calumbo. Apesar do nível de detalhamento de sua descrição, quando examinamos os números desagregados constatamos que, provavelmente, o militar contou apenas os fogos, que era o que realmente valia para fins fiscais, e aplicou as mesmas proporções para cada categoria em todos os distritos. ${ }^{47}$

Depois disso, passaram a ocorrer contagens praticamente anuais, sob a responsabilidade dos capitães mores, em torno dos principais distritos e presídios sob a soberania portuguesa, seguindo um modelo que havia sido elaborado no final do século XVIII pelo governador dom Miguel Antônio de Melo. Essas fontes vêm sendo amplamente trabalhadas pela equipe do

discutida em MARQUES, João Pedro. Os sons do silêncio: o Portugal de Oitocentos e a abolição do tráfico de escravos. Lisboa: Instituto de Ciências Sociais, 1999.

${ }^{46}$ Não é possível datar com exatidão o ano das contagens, mas no documento constam três datas: em 1792 teria começado sua viagem pelo rio Kwanza; em 1794 teria sido finalizada a contagem no primeiro presídio, Ambaca; em 1796 teria sido contado o presídio de Massangano. A viagem terminou em novembro de 1796. Francisco Antônio Pitta Bezerra d'Alpoim e Castro, posterior a 1796. AHU, Avulsos, Angola, cx. 77, doc. 85.

${ }^{47}$ Francisco Antônio Pitta Bezerra d'Alpoim e Castro, posterior a 1796. AHU, Avulsos, Angola, cx. 77, doc. 85. A contagem de fogos parece ter sido o método mais utilizado pelas autoridades de Angola nos diversos mapas populacionais, cf. SILVA, Daniel Domingues da. The early population charts of Portuguese Angola, 1776-1830, op. cit., p. 121. 
projeto Counting colonial populations e parte delas já foi publicada em seu site e em um artigo de autoria de Paulo Matos e Jelmer Vos. ${ }^{48}$

Os autores deste estudo notaram que as contagens feitas em Angola dependiam muito das condições políticas e de mobilidade das populações locais, além do maior ou menor rigor dos capitães destacados para a tarefa. ${ }^{49}$ Assim, como se observa na contagem feita em Pungo Andongo em 1797, em algumas ocasiões foram numerados apenas os moradores nas imediações do presídio, enquanto que, em outras, foram contabilizadas todas as populações avassaladas. Daí uma diferença importante entre os diversos mapas de população existentes no início do século XIX e a já citada numeração elaborada pelo capitão Castro. O segundo teve o mesmo critério para contar todas as povoações, fosse este critério qual fosse, enquanto que nos primeiros o critério variou muito. Entretanto, Paulo Matos e Jelmer Vos referem um problema que parece comum a todos os mapas e registros populacionais existentes: os números desagregados são pouco fiáveis, pois as autoridades tendiam a ter um maior conhecimento do "volume da população do que das suas características em termos de sua estrutura etária e civil". Em outras palavras, a fonte principal de praticamente todos os mapas e censos deveria ser o número de habitações, critério bem conhecido pelas autoridades angolanas, já que era utilizado para a cobrança dos dízimos. É provável, aliás, que os ramistas dos dízimos fossem algumas vezes os informantes dos capitães responsáveis pela elaboração dos mapas..$^{50}$

O exame das contagens, as gerais para todo o Reino de Angola e as específicas aos distritos e presídios, revela que o controle português sobre as populações locais era mais forte em torno do rio Kwanza: Muxima, Massangano,

\footnotetext{
${ }^{48}$ MATOS, Paulo Teodoro de $\mathcal{E}$ VOS, Jelmer. Demografia e relações laborais em Angola, 1800: um ensaio metodológico. Diálogos - Revista do Departamento de História da Universidade Estadual de Maringá, vol. 17, n 3, 2013, p. 807-834 e MATOS, Paulo et alli. Counting colonial populations. Disponível em: http://colonialpopulations.fcsh.unl.pt/. Acesso em: 14/04/2016. Ver também a discussão sobre estas fontes em CURTO, José \& GERVAIS, Raymond. A dinâmica demográfica de Luanda no contexto do tráfico de escravos do Atlântico Sul, 1781-1844. Topoi, n. 4, 2002, p. 85-138.

${ }^{49}$ Embora a Coroa tivesse controle territorial efetivo de boa parte da América portuguesa habitada por seus súditos, ainda assim os levantamentos e censos realizados no Brasil à mesma época enfrentaram problemas similares ou iguais aos realizados em Angola; cf. BOTELHO, Tarcísio. A população da América portuguesa em finais do período colonial (1776-1822): fontes e estimativas globais. Anais de História de Além-Mar, vol. XVI, 2015, p. 92.

${ }^{50}$ MATOS, Paulo Teodoro de E VOS, Jelmer. Demografia e relações laborais em Angola, op. cit., p. 13. Ainda que sejam notáveis as críticas do capitão Castro à ignorância dos ramistas, cf. Francisco Antônio Pitta Bezerra d'Alpoim e Castro, posterior a 1796. AHU, Avulsos, Angola, cx. 77, doc. 85 (antiga).
} 
Cambambe, Pedras de Pungo Andongo e Ambaca tiveram suas populações assentadas por reiteradas vezes e, com a exceção de Muxima, ainda em 1684 foi informado ao rei a quantidade de lideranças avassaladas nesses presídios. Também existem muitos mapas de população para os distritos de Icolo/Bengo, Dande e para o presídio de Encoje. Todas essas divisões administrativas concentravam uma população entre 150 e 250 mil pessoas (ver apêndice).

Por outro lado, apenas nos censos gerais de 1819 e 1845 aparecem referências a alguns sobados no planalto de Benguela: Dembo Grande da Quitamba, Bailundo, Humbo, Galengue e Sambos Bihé, Quilengues e Sambos, Quilengues e Huila. Nestas zonas não havia presídios ou capitães e as populações locais eram bastante autônomas frente às autoridades lusitanas; talvez por isso que, na percepção de alguns militares e traficantes portugueses, os "Benguela" eram mais "ferozes", enquanto os escravos Angola eram mais "acostumados" com a dominação portuguesa. ${ }^{51}$ Alguns desses lugares em Benguela são mencionados por Elias Alexandre da Silva Corrêa como uma "prolongação da Conquista fomentada pelo comércio". ${ }^{52}$ Os dados referentes a esta região apontam para uma população entre 100 mil e 120 mil almas. São, contudo, simples estimativas, como fica muito claro pelo levantamento demográfico apresentado em 1819 (ver apêndice).

Todas essas considerações permitem concluir que o censo de 1777 incluía um território muito similar aos de 1819 e 1845, ou seja, abrangendo as povoações submetidas ao governo geral de Angola e ao governador de Benguela, contando ainda as referidas zonas no interior de Benguela.

Recapitulando, portanto, a curva da população traçada pelos censos gerais de 1777, 1819 e 1845 apresenta a forma de um arco voltado para baixo: queda entre 1777 e 1819 e crescimento entre 1819 e 1845 . Do mesmo modo, a população de Luanda, segundo os dados muito mais abrangentes organizados por Curto, mostra uma tendência relativamente parecida, mas as oscilações são obviamente muito mais expressivas. $\mathrm{O}$ ponto mais baixo encontra-se na década de 1810, como se verifica pelo gráfico 2.

\footnotetext{
${ }^{51}$ Cf. o processo de Manoel Antônio Pereira, homem de negócio de Lisboa, contra o seu correspondente em Lisboa, Manoel da Costa Pinheiro, em que o acusa de negligência com uma carga de escravos Benguela por não andarem acorrentados no navio. ANTT, Feitos findos, Conservatória da Companhia de Pernambuco e Paraíba, maço 27, n. 1, caixa 35.

${ }^{52}$ CORRÊA, Elias Alexandre. História de Angola, vol. 1. Lisboa: Editorial Ática, 1937 (1792), p. 26.
} 


\section{Gráfico 2}

\section{Evolução da população de Luanda}

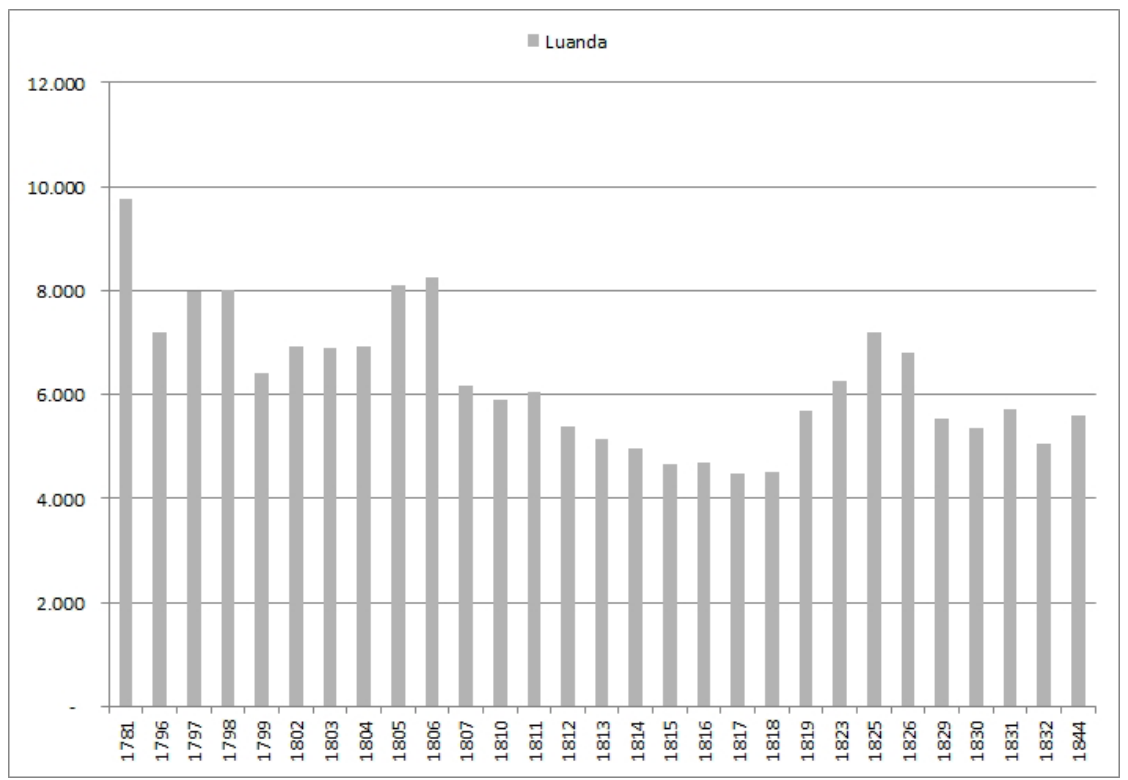

Fonte: CURTO, José \& GERVAIS, Raymond. A dinâmica demográfica de Luanda no contexto do tráfico de escravos do Atlântico Sul, 1781-1844. Topoi, n. 4, 2002, p. 115-116.

Podemos agora comparar a evolução demográfica dos distritos que foram considerados pela convenção dos dízimos feita pelo capitão Castro e as diversas contagens publicadas pela equipe do Counting colonial populations, de maneira a verificar se ela corrobora a tendência apresentada pelos censos gerais. O apêndice e os gráficos 3 e 4 apresentam os dados por presídio/distrito. Em alguns casos há uma variação muito grande entre alguns anos, em razão das já referidas variações nas metodologias das contagens. O presídio de Pedras de Pungo Andongo é o melhor exemplo disto. Apesar de possuir um número grande de sobas submetidos (entre 20 e 30), nos anos de 1797, 1800 e 1810 sua população registrada foi ínfima. Ambaca é outro presídio que certamente teve sua população subestimada, pois, em 1797, o capitão local anotou que não era possível apresentar a quantidade de mulheres "que só por aproximação pode reputar-se o triplo do número de todos os povoadores". Por este cálculo habitariam em torno do presídio umas 100 mil 
pessoas avassaladas, número relativamente próximo ao contabilizado pelo capitão Castro entre 1792-1796. ${ }^{53}$

Seja como for, organizando os dados de oito presídios/distritos para os quais possuímos um número maior de contagens (pelo menos seis) em dois gráficos diferentes, chegamos ao seguinte resultado:

\section{Gráfico 3}

\section{Evolução populacional em alguns distritos/presídios de Angola}

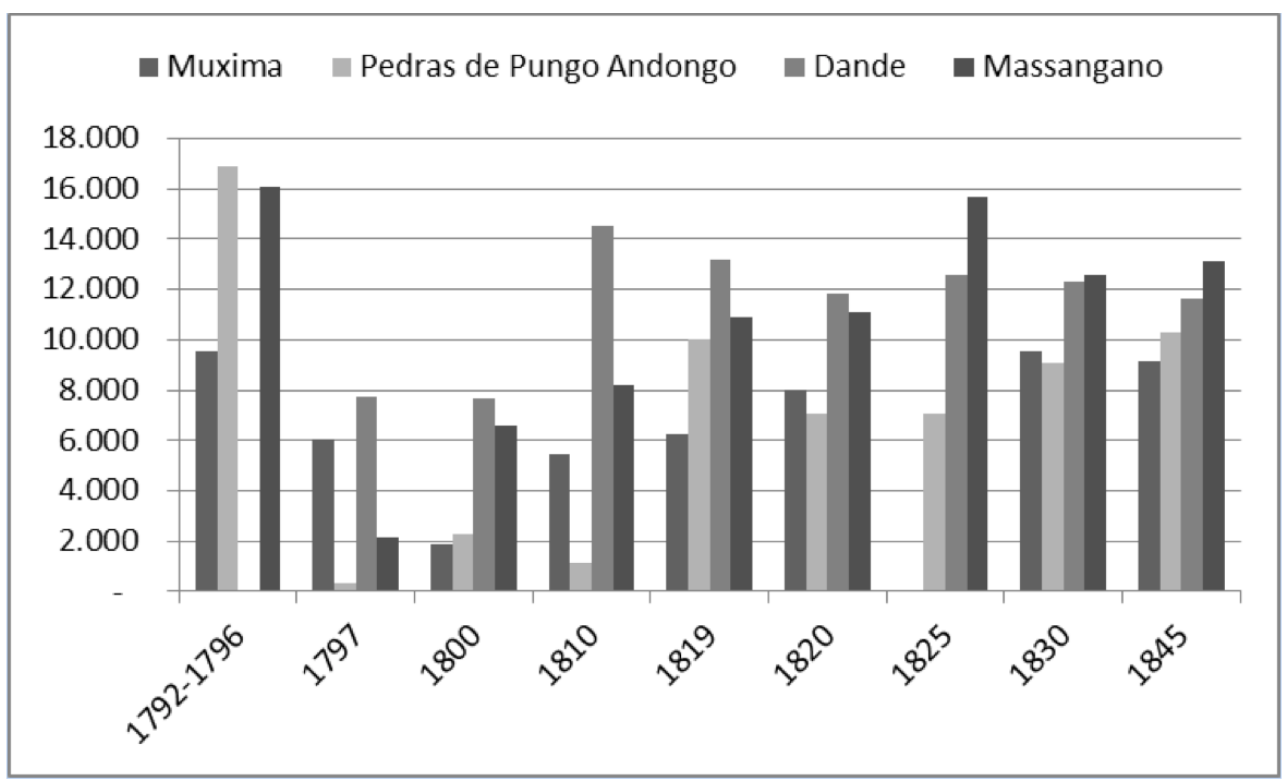

Fontes: Ver apêndice.

\footnotetext{
${ }^{53}$ AHU, CU, Angola, cx. 86, doc. 76, de acordo com as planilhas de MATOS, Paulo et alli. Counting co-
} lonial populations. Disponível em: http://colonialpopulations.fcsh.unl.pt/. Acesso em: 14/04/2016. 


\section{Gráfico 4}

\section{Evolução populacional em alguns distritos/presídios de Angola}

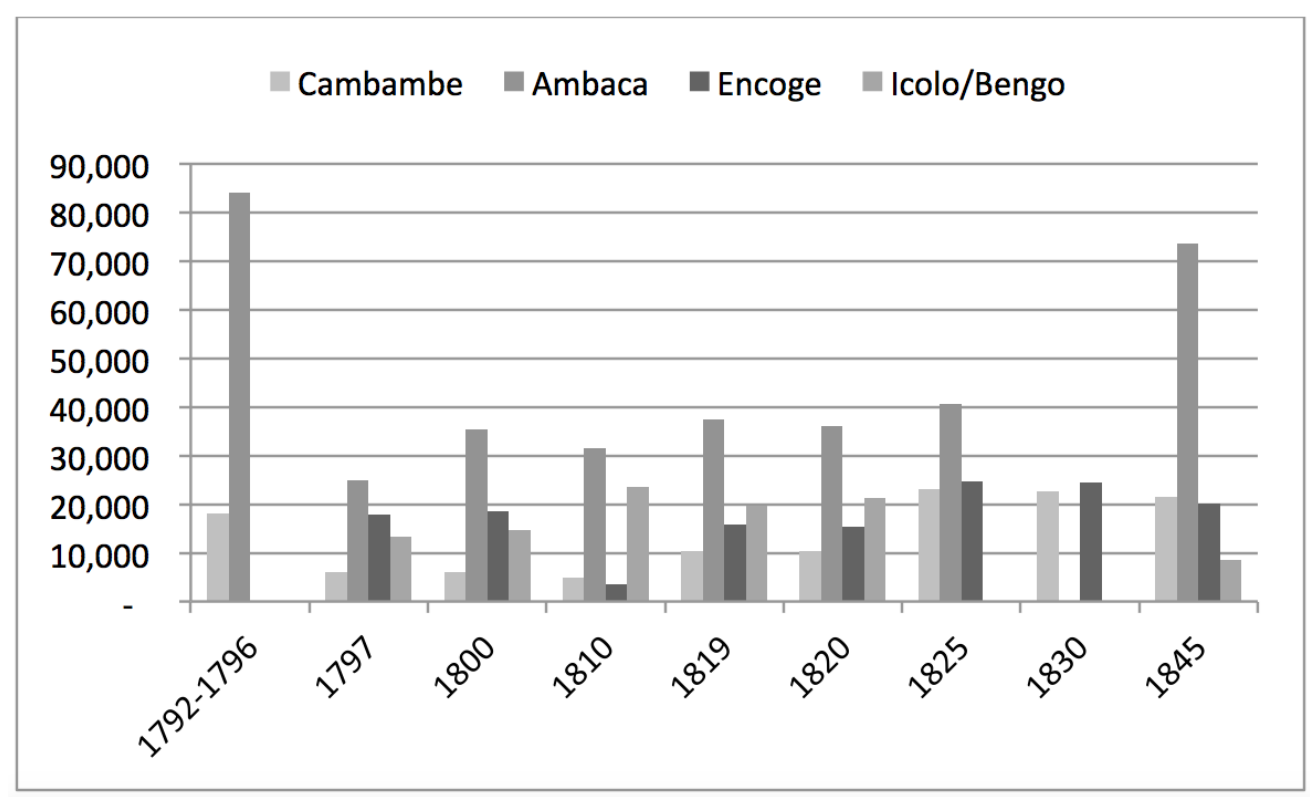

Fontes: ver apêndice.

Em síntese, todos os presídios que foram visitados pelo capitão Castro apresentam a mesma curva em arco das contagens gerais, com uma forte inflexão - situada entre 1797 e 1800 -, seguida de uma recuperação posterior, ainda que sujeita a algumas oscilações. É possível obstar esta análise pelo seu ponto de partida: a contagem do capitão Castro não seria um bom início, haja vista que o caráter fiscal do seu assento e o excesso de zelo ou de imaginação do militar podem ter resultado num cálculo mais abrangente ou exagerado do que todas as contagens posteriores. Os mapas de 1797, apresentando valores muito inferiores num intervalo de tempo quase imediato à viagem do oficial pelo rio Kwanza, seriam uma indicação importante dessa distorção.

Quanto à primeira hipótese, de que o levantamento do capitão Castro foi mais rigoroso e abrangente, deve-se notar que os valores de 1797, 1800, 1810, 1820, 1825 e 1830 foram sempre inferiores aos de 1792-1796, apesar da mudança dos oficiais responsáveis pela produção dos mapas. Ou seja, teríamos de aceitar a ideia de que todos os capitães de presídios foram menos cuidadosos ou tiveram critérios diferentes. A comparação direta com os mapas de 1797 tampouco é um argumento válido, pois em 1797, nos presídios de Pedras de Pungo Andongo e Ambaca, a população foi claramente subestimada. 
Por outro lado, teria o referido oficial inventado números fantásticos? Um cálculo simples permite testar se a contagem de 1792-1796 é uma grandeza de valor aceitável, segundo os censos gerais. Em 1819, a população dos territórios visitados pelo referido capitão Francisco Antônio Pitta Bezerra d'Alpoim e Castro equivalia a 26\% do total, e em 1845, a 35\% da população de todo o Reino de Angola. Sendo assim, podemos considerar que a participação dos referidos distritos na demografia do Reino de Angola deve ter variado entre 25\%, 30\% e 35\%. Por esta acepção, é possível estimar que a população total do Reino de Angola em 1792/1796 poderá ter sido, segundo as proporções respectivas, de 591.664, 493.053 ou 422.617 pessoas, números relativamente próximos ao censo de 1777 e completamente verossímeis.

Deve-se notar ainda que as curvas dos presídios/distritos diferem em muitos aspectos da curva de Luanda, especialmente pelo ponto mais baixo da população da capital estar situado na década de 1810. Entretanto, a demografia da capital corrobora o sentido mais geral de redução que parece ter ocorrido na década de 1790, ainda que os seus movimentos populacionais estejam muito mais associados ao comércio atlântico do que as povoações do interior.

\section{Conclusões}

Sintetizando tudo o que foi discutido até aqui, podemos traçar três tendências demográficas: a primeira, pelas estimativas baseadas nos valores dos dízimos e nos números dos sobas; a segunda baseada nas contagens agregadas; e a terceira, nos levantamentos demográficos parciais. Sendo assim:

a) Os dízimos apresentam leve crescimento entre 1717 e 1765. A contagem dos sobas revela um aumento no número de lideranças entre 1684 e 1797 ou 1810.

b) Pelos censos gerais, temos redução demográfica entre 1777 e 1819, e leve recuperação em 1845.

c) Pelas contagens parciais, o movimento demográfico de Luanda apresenta queda acentuada desde 1781, alcançando o seu ponto mais baixo em 1818, recuperação na década de 1820 e oscilações entre 1830 e 1840 quando as séries tornam-se mais incompletas. Entre os presídios/distritos temos uma forte redução entre 1792/1796 e 1797/1800 em praticamente todos os distritos, recuperação geral até 1810 e crescimento relativamente constante nos números registrados para 1819, 1820, 1825, 1830 e 1845, ainda que existam oscilações em alguns distritos particulares. 
Finalmente, podemos responder a pergunta principal do artigo, se houve aumento ou redução na população do Reino de Angola. Para o século XVIII, as evidências são menos abalizadas, entretanto, tudo indica que houve um leve crescimento nas zonas próximas ao Kwanza, onde a conquista era mais consolidada. Este crescimento parece ser sustentado por um movimento da fronteira da escravização, como argumentou originalmente Miller, pois a documentação, a bibliografia e os registros de exportação mostram que o interior de Benguela foi uma das principais fontes de escravos durante o século XVIII, inclusive quando exportados por Luanda, o que pode ter favorecido a demografia das populações avassaladas no hinterland da capital, tanto pela diminuição da violência, permitindo o crescimento vegetativo da população, como pela agregação de cativos capturados ao sul. Bem entendido que o conceito de "fronteira da escravização" deve ser encarado à maneira de Mariana Candido, de forma flexível e múltipla, haja vista a permanência da violência escravizadora nas zonas sob a suserania lusitana, a geração de cativos no interior dessas fronteiras e as diversas ondas de escravização tanto a leste como a sul e norte. Por outro lado, e este parece ser o fator mais relevante, ampliaram-se o território e as populações teoricamente submetidas ao domínio lusitano. O aumento no número de lideranças é o melhor argumento nesse sentido. $\mathrm{O}$ aumento populacional, se é que houve, pode ter sido puramente extensivo. No final do século XVII, é pouco provável que mais de 150 mil pessoas estivessem avassaladas ao rei português; já na década de 1770, a população havia triplicado, principalmente pelo aumento do território ao sul, em Benguela, mas também ao norte, em Encoje. ${ }^{54}$

A partir da década de 1780 a tendência parece ser para a baixa: a população não recuperou os números de 1777 antes do fim do tráfico. A análise das contagens parciais dos presídios sugere que a inflexão ocorreu efetiva-

\footnotetext{
${ }^{54}$ CANDIDO, Mariana. Fronteras de la esclavización, op. cit., p. 157-158. M. Candido ressalta a importância de Benguela no fornecimento de escravos durante o século XVIII. Contudo, suas críticas ao TSTD por uma subestimação das exportações ao sul de Luanda devem ser encaradas com algumas reservas já que os cativos de Benguela eram majoritariamente despachados por Luanda até a década de 1760 , onde pagavam os direitos e reais e eram devidamente registrados pelas autoridades. Sobre isto ver Rodrigo Cesar de Menezes, 22/12/1734. AHU, Avulsos, Angola, cx. 30, doc. 2971. Consultar ainda o caso do navio Nossa Senhora de Guadalupe que fez seu resgate inteiramente em Benguela, mas despachou sua carga em Luanda (Requerimento de Manoel José da Costa Pinheiro, 1763. AHU, Avulsos, Angola, cx. 48, doc. 19), como consta na lista dos administradores anexada na correspondência de Antônio de Vasconcelos, 30/03/1764. AHU, Avulsos, Angola, cx. 48, doc. 6. Para as críticas de Candido ver CANDIDO, Mariana P. An African slaving port and the Atlantic world, op. cit., p. 152 et passim.
} 
mente por volta de 1792/1796 e que o ponto culminante na debacle demográfica ocorreu na virada do século. Como explicar esta queda? Qual a sua relação com o tráfico de escravos?

As exportações de pessoas de Angola e Benguela registram um forte crescimento na década de 1790, como se verifica no gráfico 5. Entretanto, a manutenção de valores altos nas deportações no início do século XIX, quando houve crescimento populacional, mostra que o Reino de Angola era capaz de sustentar a deportação de 200 mil pessoas em uma década e ainda assim manter uma demografia positiva. Esta afirmação, contudo, pode ser relativizada pelo movimento demográfico da capital que parece ser negativo durante quase todo o período.

A redução populacional do Reino de Angola durante a década de 1790 pode ter outras causas, portanto. Como já visto, a baixa produtividade da agricultura na zona Congo-Angolana sujeitava as populações locais às fortes variações climatológicas da região, produzindo fomes periódicas. A bibliografia e os testemunhos da época sugerem que houve uma crise agrária de grandes dimensões nesse período. Os anos de 1791-1792 foram marcados pela ocorrência de um El Niño de forte intensidade, com efeitos sobre todo o Atlântico sul. Uma seca que atingiu as duas margens do Atlântico sul destruiu a pecuária no nordeste do Brasil e afetou também as populações da África centro-ocidental. No caso do Reino de Angola sucedeu uma crise de abastecimento que se estendeu até 1794, potencializada por sucessivas ondas de gafanhotos. ${ }^{55}$ Simultaneamente, ao norte de Luanda ocorria uma guerra de grande escala contra o marquês do Mussulo ao norte do rio Dande. Segundo a crônica de Elias Alexandre da Silva Corrêa, a operação do Exército português resultou na destruição de 287 libatas e banzas, podendo ter levado à destruição das casas e plantações de uma população entre 30 e 90 mil pessoas aproximadamente, além da desorganização dos cultivos das populações avassaladas que deveriam fornecer os carregadores e a guerra preta para o Exército português. ${ }^{56}$ Mais ou menos ao mesmo tempo, o capitão

\footnotetext{
${ }_{55}$ Manoel de Almeida Vasconcelos, 25/04/1793. AHU, Avulsos, Angola, cx. 78, doc. 59; Manoel de Almeida Vasconcelos, 24/08/1793. AHU, Avulsos, Angola, cx. 79, doc. 26; e Manoel de Almeida Vasconcelos, 03/03/1794. AHU, Avulsos, Angola, cx. 80, doc. 21. MILLER, Joseph. The significance of drought, disease and famine, op. cit., p. 53-54. Sobre o El Niño e suas consequências no Brasil ver: MENZ, Maximiliano. Entre impérios: formação do Rio Grande na crise do sistema colonial português. São Paulo: Alameda, 2009.

${ }^{56}$ CORRÊA, Elias Alexandre. História de Angola, vol. 2, op. cit., p. 232. Calculamos o número de pessoas afetadas de dois modos: pelo primeiro, multiplicamos o número de libatas destruídas
} 
Castro estava registrando uma expressiva população submetida em torno do Kwanza. Seus números podem ser o resultado de migrações das zonas mais árida para as regiões sob a suserania lusitana. Uma segunda etapa na crise da década de 1790 se desenrolou entre 1797 e 1802, quando uma segunda onda de más colheitas teria provocado o despovoamento generalizado, registrado pelos recenseamentos posteriores..$^{57}$

Existe sólida evidência empírica da correlação entre guerras, fomes e colapsos agrários nas sociedades pré-industriais. Entretanto, no caso de Angola, esses fenômenos não podem ser analisados separadamente das pressões escravizadoras e da violência promovida pelas autoridades portuguesas. A crise da década de 1790 foi precedida pela lenta recuperação dos preços dos escravos no Brasil, pela ampliação das exportações, principalmente de Benguela, e pelas tentativas portuguesas em controlar os pontos de comércio de escravos ao norte de Luanda. O crescimento dos preços de produtos tropicais por causa dos conflitos europeus, a ampliação da agricultura escravista nas zonas tradicionais no norte do Brasil, a abertura de novas frentes de expansão do escravismo no sul e a expansão industrial europeia estão entre os muitos fatores que favoreceram a ampliação da violência e a extração de pessoas, potencializando o colapso agrário do período. Seja como for, a pressão escravista precedeu o colapso como se pode constatar no gráfico $5 .^{58}$

por 120, considerando que Lazló Magyar, que havia visitado Angola nos anos 1850, afirmava que cada libata continha entre 80 e 160 moradores, sem contar as crianças, chegando a 34.400 pessoas. O segundo cálculo baseia-se na afirmação de Correa (p. 207) de que, durante as operações contra o duque de Quina, foram atacadas 37 libatas, resultando na destruição de 4.000 casas. Deste modo, calculou-se que para cada libata seriam 108 casas, totalizando assim 31.027 moradias queimadas pelo Exército português; seguindo a estimativa de três pessoas por fogo, chega-se a 93.081 almas afetadas. A estimativa de Lazló Magyar consta em HEYWOOD, Linda $\mathcal{E}$ THORNTON, John. African fiscal systems as sources for demographic history: the case of Central Angola, 1799-1920. The Journal of African History, vol. 29, n. 2, 1988, p. 213-228, p. 214.

57 Sobre as migrações das zonas mais áridas para as menos áridas no contexto das secas ver DIAS, Jill. Famine and disease in the history of Angola, op. cit., p. 355-357. Para a cronologia de secas e fomes, ver CURTO, José \& GERVAIS, Raymond, op. cit., p. 122.

${ }^{58}$ Sobre as transformações estruturais do escravismo entre o final do século XVIII e início do XIX ver TOMICH, Dale. Pelo prisma da escravidão. São Paulo: Edusp, 2013 e BERBEL, Márcia; MARQUESE, Rafael; PARRON, Tamis. Escravidão e política, Brasil e Cuba. São Paulo: Hucitec, 2010. Sobre as mudanças no Império português no final do XVIII ver ARRUDA, José J. Decadência ou crise do Império luso-brasileiro: o novo padrão de colonização do século XVIII. Revista USP, n. 46, São Paulo, jun./ago. 2000, p. 66-78. 


\section{Gráfico 5 \\ Exportações de escravos por década (Angola + Benguela)}

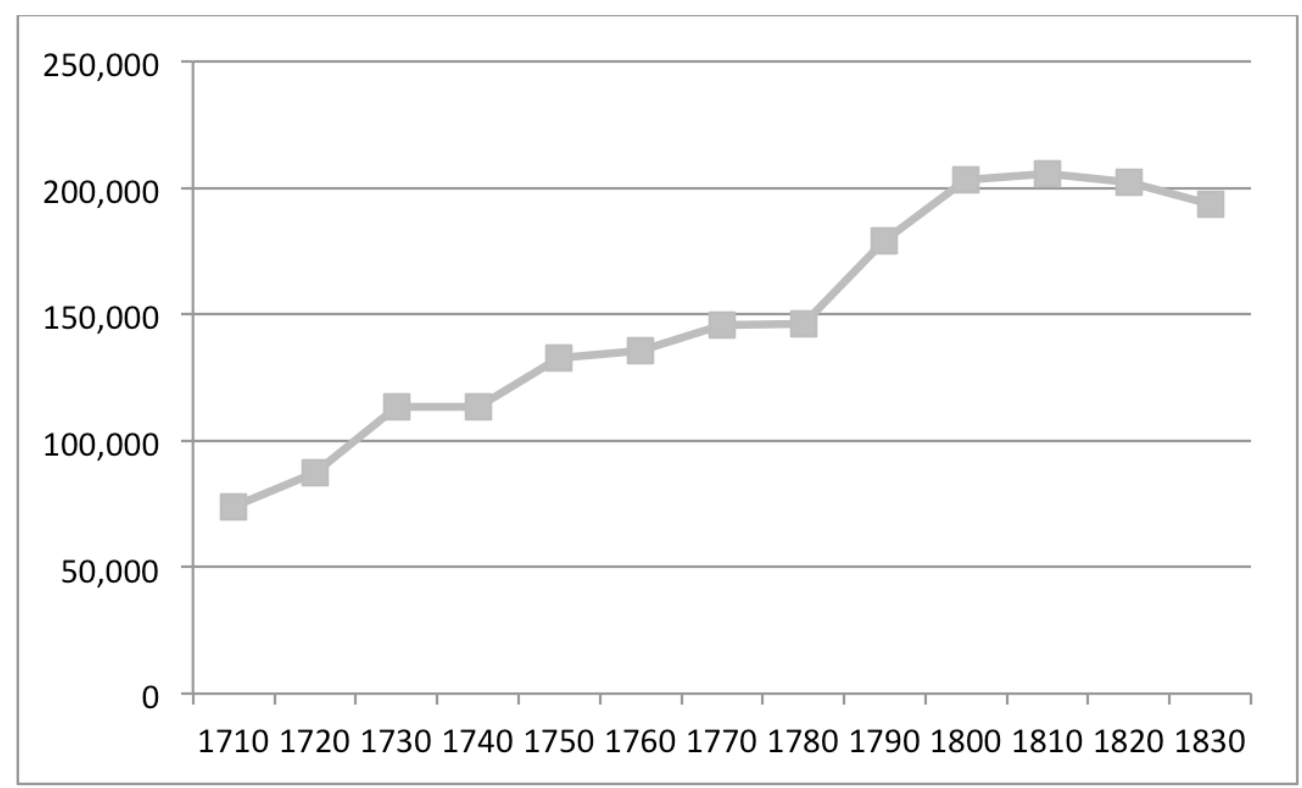

Fonte: TSTD, 2010. Acesso em: 12/11/2012 e CURTO, José C. Álcool e escravos. O comércio luso-brasileiro do álcool em Mpinda, Luanda e Benguela durante o tráfico atlântico de escravos (c. 1480-1830) e o seu impacto nas sociedades da África central e ocidental. Tradução. Lisboa: Vulgata, 2002.

A conclusão mais segura a que podemos chegar com os números analisados neste artigo é que houve redução na população do Reino de Angola entre o final do século XVIII e o início do século XIX. Por outro lado, ainda que a "crise malthusiana" tenha sido decisiva, as evidências que sugerem que o aumento da pressão escravista precedeu o colapso agrário, a lenta recuperação populacional na primeira metade do século XIX e o rápido crescimento após 1845 demonstram como o tráfico de escravos teve um impacto negativo sobre as populações submetidas à autoridade portuguesa na zona Congo-Angolana. ${ }^{59}$

\footnotetext{
${ }^{59}$ Vale acrescentar que o crescimento populacional verificado por Thornton e Heywood entre os ovimbundos, de 1799 a 1850, por comparar um período de população muito baixa (após a crise da década de 1790) com outro de forte recuperação (a diminuição da pressão escravizadora na década de 1840), acaba por esconder flutuações demográficas violentas.
} 


\section{Apêndice}

\section{População por distrito do Reino de Angola, segundo as diversas contagens analisadas}

\begin{tabular}{|c|c|c|c|c|c|c|c|c|c|}
\hline localidades/ano & $\begin{array}{l}1792- \\
1796\end{array}$ & 1797 & 1800 & 1810 & 1819 & 1820 & 1825 & 1830 & 1845 \\
\hline cidade de Luanda & & & 5.702 & 5.617 & 4.518 & 5.680 & & & 5.605 \\
\hline Muxima & 9.546 & 6.059 & 1.861 & 5.434 & 6.280 & 7.970 & & 9.549 & 9.168 \\
\hline Massangano & 16.056 & 2.180 & 6.564 & 8.190 & 10.910 & 11.066 & 15.648 & 12.557 & 13.114 \\
\hline Cambambe & 18.200 & 5.950 & 6.143 & 4.960 & 10.320 & 10.352 & 22.829 & 22.750 & 21.546 \\
\hline $\begin{array}{l}\text { Pedras de Pungo } \\
\text { Andongo }\end{array}$ & 16.870 & 368 & 2.317 & 1.153 & 10.000 & 7.061 & 7.061 & 9.086 & 10.291 \\
\hline Ambaca & 84.167 & 25.018 & 35.399 & 31.524 & 37.550 & 35.964 & 40.735 & & 73.369 \\
\hline Encoge & & 17.944 & 18.609 & 3.517 & 15.790 & 15.421 & 24.792 & 24.449 & 20.128 \\
\hline Icolo/Bengo & & 13.135 & 14.757 & 23.330 & 19.730 & 21.290 & & & 8.526 \\
\hline Dande & & 7.701 & 7.675 & 14.513 & 13.200 & 11.803 & 12.569 & 12.298 & 11.652 \\
\hline Golungo & & & 60.051 & 68.708 & 59.065 & 12.373 & & & 64.348 \\
\hline Calumbo & 3.077 & & & & 18.000 & & & 5.317 & 8.262 \\
\hline Zenza/Quilengues & - & & & & 7.117 & & & & \\
\hline total Angola & & & & & 212.480 & & & & 246.009 \\
\hline total da contagem & 147.916 & 78.355 & 159.078 & 166.946 & 212.480 & 138.980 & 123.634 & 96.006 & 246.009 \\
\hline $\begin{array}{c}\text { cidade de S. Felipe de } \\
\text { Benguela }\end{array}$ & & & 2.007 & & 2.397 & 2.249 & 2.419 & & 2.438 \\
\hline Novo Redondo & & 593 & 293 & & 8.000 & - & & & 547 \\
\hline Caconda & & & 13.364 & & 14.560 & 20.203 & 21.842 & 22.113 & 22.100 \\
\hline Mossamedes & & & & & & & & & 8.166 \\
\hline $\begin{array}{c}\text { Dembo Grande da } \\
\text { Quitamba }\end{array}$ & & & & & 8.000 & & & & 7.994 \\
\hline Bailundo & & & & & 56.000 & & & & 50.309 \\
\hline $\begin{array}{c}\text { Humbo, Galengue e } \\
\text { Sambos }\end{array}$ & & & & & 15.000 & & & & 9.852 \\
\hline $\begin{array}{c}\text { Bihé, Quilengues e } \\
\text { Sambos, Quilengues } \\
\text { e Huila }\end{array}$ & & & & & 42.000 & & & & 39.108 \\
\hline total Benguela & & & & & 145.957 & & & & 140.514 \\
\hline Total geral & & & & & $\mathbf{3 5 8 . 4 3 7}$ & & & & 386.523 \\
\hline
\end{tabular}




\begin{abstract}
Legenda: em vermelho estão os números que claramente estão "fora da curva"; em verde uma correção frente à planilha original publicada em MATOS, Paulo et alli. Counting colonial populations. Disponível em: http://colonialpopulations.fcsh.unl.pt/. Acesso em: 14/04/2016; em azul, contagens de 1829 que classificamos para 1830. Em itálico, na linha total da contagem, somamos o conjunto da população que consta em Angola segundo as diversas contagens parciais existentes. Em 1845, há uma pequena diferença entre o total geral original (386.463) e o total obtido pela soma das parciais (386.523).
\end{abstract}

Fontes: 1792-1796: Francisco Antônio Pitta Bezerra d'Alpoim e Castro, posterior a 1796, 1797, 1820, 1825 e 1830, AHU, Avulsos, Angola, cx. 77, doc. 85 (antiga), de acordo com as planilhas de MATOS, Paulo et alli. Counting colonial populations. Disponível em: http://colonialpopulations.fcsh.unl.pt/. Acesso em: 14/04/2016; 1800 e 1810: MATOS, Paulo Teodoro de $\mathcal{E}$ VOS, Jelmer. Demografia e relações laborais em Angola, 1800: um ensaio metodológico, op. cit., p. 818-819; 1819: TORRES, João C. F. Memórias contendo a biographia do vice-almirante Luiz da Motta Feo e Torres em A história dos governadores e capitães gerais de Angola, desde 1575 até 1825 e a Descripção geographica e política dos reinos de Angola e Benguela. Paris: Fantin Livreiro, 1825, p. 352-375; 1845: LIMA, José Joaquim Lopes de. Ensaios sobre a statistica das possessões portuguezas no Ultramar, livro III, de Angola e Benguella e suas dependências. Lisboa: Imprensa Nacional, 1846.

\title{
Referências bibliográficas
}

ALEXANDRE, Valentim. Portugal e a abolição do tráfico de escravos (1834-1851). Análise Social, vol. XXVI, n. 111, 1991 (2), p. 293-333.

ARRUDA, José. Decadência ou crise do Império luso-brasileiro: o novo padrão de colonização do século XVIII. Revista USP, n. 46, São Paulo, jun./ago. 2000, p. 66-78.

BERBEL, Marcia; MARQUESE, Rafael; PARRON, Tamis. Escravidão e política, Brasil e Cuba, 1790-1850. São Paulo: Hucitec, 2010.

BETHELL, Leslie. A abolição do tráfico de escravos no Brasil: a Grã-Bretanha, Brasil e a questão do tráfico de escravos, 1807-1869. Rio de Janeiro: Expressão e Cultura; São Paulo: Edusp, 1976.

BIRMGHAM, David. Trade and conflict in Angola. The Mbundu and their neighbours under the influence of the Portuguese, 1483-1790. Oxford: Clarendon Press, 1966.

BOTELHO, Tarcísio R. A população da América portuguesa em finais do período colonial (1776-1822): fontes e estimativas globais. Anais de História de Além-Mar, vol. XVI, 2015, p. 79-106.

BRAUDEL, Fernand. Civilização material, economia e capitalismo. As estruturas do cotidiano, vol. 1. São Paulo: Martins Fontes, 1997.

CANDIDO, Mariana. An African slaving port and the Atlantic world: Benguela and its hinterland. Nova York: Cambridge University Press, 2013.

Fronteras de la esclavización: Esclavitud, comercio, e identidad en Benguela, 17801850. México, D.F.: El Colegio de México, Centro de Estudios de Asia y África, 2011.

CARRARA, Ângelo. Minas e currais. Produção rural e mercado interno de Minas Gerais, 1674-1807. Juiz de Fora: Editora da UFJF, 2007. 
CARREIRA, Antônio. Angola: da escravatura ao trabalho livre. Subsídios para a história demográfica do século XVI até a independência. Lisboa: Arcádia, 1977.

CONRAD, Robert. Tumbeiros: o tráfico escravista para o Brasil. São Paulo: Brasiliense, 1985.

CURTO, José. The anatomy of a demographic explosion: Luanda, 1844-1850. The International Journal of African Historical Studies, vol. 32, n. 2/3, 1999, p. 381-405.

CURTO, José \& GERVAIS, Raymond. A dinâmica demográfica de Luanda no contexto do tráfico de escravos do Atlântico Sul, 1781-1844. Topoi, n. 4, 2002, p. 85-138.

DELGADO, Ralph. História de Angola. 4 volumes. Benguela/Lobito: Edições do Banco de Angola, 1948-1955.

DIAS, Jill. Famine and disease in the history of Angola c. 1830-1930. The Journal of African History, n. 22, p. 349-378.

ELTIS, David. Economic growth and the ending of the transatlantic slave trade. Nova York: Oxford University Press, 1987.

ELTIS, David \& RICHARDSON, David. A new assessment of the transatlantic slave trade. In: Idem (ed.). Extending the frontiers: essays in the new transatlantic slave trade. Yale, CT.: Yale University Press, 2008.

FAGE, John. African societies and the Atlantic slave trade. Past and Present, vol. 125, n. 1, 1989, p. 111-115.

FERREIRA, Roquinaldo. The suppression of the slave trade and slave departures from Angola, 1830s-1860s. História Unisinos, vol. 15, n. 1, jan./abr. 2011, p. 3-13.

FLORENTINO, Manolo. The slave trade, colonial markets, and slave families in Rio de Janeiro, Brazil, ca. 1790-ca. 1830. In: ELTIS, David \& RICHARDSON, David (ed.). Extending the frontiers. Essays on the new transatlantic slave trade database. New Haven: Yale University, 2008.

GONÇALVES, Antônio. A história revistada do Kongo e de Angola. Lisboa: Estampa, 2005.

GREEN, Toby. The rise of the trans-Atlantic slave trade in Western Africa, 1300-1589. Nova York: Cambridge University Press, 2012.

HALL, Gwendolyn Midlo. Slavery and African ethnicities in the Americas: restoring the links. Chapel Hill: University of North Carolina Press, 2005.

HEINTZE, Beatrix. A política econômica e de colonização portuguesa em Angola de 1570 a 1607. In: Idem. Angola nos séculos XVI e XVII. Estudos sobre fontes, métodos e história. Luanda: Kilombelombe, 2007.

As fontes da história pré-colonial de Angola ou a maravilhosa viagem dos jagas através dos séculos. In: Idem. Angola nos séculos XVI e XVII. Estudos sobre fontes, métodos e história. Luanda: Kilombembe, 2007.

HENRIQUES, Isabel de Castro. A organização afro-portuguesa do tráfico de escravos (séculos XVII-XIX). In: HENRIQUES, I. de C. \& MEDINA, João. A rota dos escravos: Angola e a rede do comércio negreiro. Lisboa: Segia, 1996.

HEYWOOD, Linda. Slavery and its transformations in the Kingdom of Kongo: 1491-1800. The Journal of African History, n. 50, 2009, p. 1-22.

HEYWOOD, Linda $\mathcal{E}$ THORNTON, John. African fiscal systems as sources for demographic history: the case of central Angola, 1799-1920. The Journal of African History, vol. 29, n. 2, 1988. 
KULA, Witold. Problemas y métodos de la história económica. $3^{\mathrm{a}}$ edição. Madri: Ediciones Península, 1977.

LADURIE, Emmanuel. História dos camponeses franceses. 2 volumes. Rio de Janeiro: Civilização Brasileira, 2007.

LANDES, D. Las estadísticas como fuente para la historia de Europa Ocidental. In: LORWIN, Val \& PRICE, Jacob (int.). Las dimensiones del pasado. Estudios de historia cuantitativa. Madri: Alianza Universidad, 1974.

LOPES, Gustavo Acioli \& MENZ, Maximiliano M. Resgate e mercadorias: uma análise comparada do tráfico luso-brasileiro em Angola e na Costa da Mina (século XVIII). Afro-Ásia, no 37, 2008.

LOVEJOY, Paul. The impact of the Atlantic slave trade on Africa: A review of the literature. The Journal of African History, vol. 30, n. 3, nov. 1989, p. 365-94.

A escravidão na África: uma história de suas transformações. Rio de Janeiro: Civilização Brasileira, 2002.

MANNING, Patrick. Escravidão e mudança social na África. Novos Estudos, n. 21, jul. 1988, p. 8-29. CUP, 1995.

. Slavery and African life. Occidental, Oriental and African slave trade. Cambridge:

MARQUES, João Paulo. Os sons do silêncio: o Portugal de Oitocentos e a abolição do tráfico de escravos. Lisboa: Instituto de Ciências Sociais, 1999.

MATOS, Paulo Teodoro de $\mathcal{E}$ VOS, Jelmer. Demografia e relações laborais em Angola, 1800: um ensaio metodológico. Diálogos - Revista do Departamento de História da Universidade Estadual de Maringá, vol. 17, nº 3, 2013, p. 807-834.

M'BOKOLO, Elikia. África negra: história e civilizações, vol. 1: O século XVIII. Lisboa: Colibri, 2007.

MENZ, M. Entre impérios: formação do Rio Grande na crise do sistema colonial português. São Paulo: Alameda, 2009.

MILLER, Joseph. The numbers, origins, and destinations of slaves in the eighteenthcentury Angolan slave trade. In: INIKORI, Joseph E. \& ENGERMAN, Stanley L. (ed.). The Atlantic slave trade: efects on economies, societies and peoples in Africa, the Americas and Europe. Durham, Londres: Duke University Press, 1992, p. 77-116.

Way of death. Merchant capitalism and the Angolan slave trade, 1780-1830. Madison, Wisconsin: University of Wisconsin, 1988.

The significance of drought, disease and famine in the agriculturally marginal zones of West-Central Africa. The Journal of African History, vol. 23, n. 1, jan. 1982.

PARREIRA, Antonio. Economia e sociedade em Angola. Na época da rainha Jinga. Lisboa: Editorial Estampa, 1990.

RODNEY, Walter. A history of the upper Guinea coast, 1545-1800. Nova York: Monthly Review, 1980.

RODRIGUES, Jaime. O fim do tráfico transatlântico de escravos para o Brasil: paradigmas em questão. In: GRINBERG, K. E SALLES, R. O Brasil imperial, vol. II, 1831-1889. Rio de Janeiro: Civilização Brasileira, 2009. 
SILVA, Daniel Domingues da. The Atlantic slave trade from West Central Africa, 1780-1867. Nova York: Cambridge UP, 2017.

The early population charts of Portuguese Angola, 1776-1830: a preliminary assessment. Anais de História do Além-Mar, vol. XVI, 2015, p. 107-24.

SILVA, Filipa Ribeiro da $\mathcal{E}$ SOMMERDYK, Stacey. Reexamining the geography and merchants of the West Central African slave trade: looking behind the numbers. African Economic History, vol. 38, 2010, p. 77-105.

SMALLWOOD, Stephanie E. Saltwater slavery: a middle passage from Africa to American diaspora. Cambridge, MA: Harvard University Press, 2007.

SPARKS, Randy. Where the Negroes are masters. An African port in the era of the slave trade. Cambridge, MA: Harvard University Press, 2014.

THORNTON, John. A África e os africanos na formação do mundo atlântico: 1400-1800. Rio de Janeiro: Campus, 2004,

Early Kongo Portuguese relations: a new interpretation. History in Africa, vol. 8, 1981, p. 183-204.

The slave trade in eighteenth century Angola: effects on demographic structures. Canadian Journal of African Studies, vol. 14, n. 3, 1980.

TOMICH, Dale. Pelo prisma da escravidão. São Paulo: Edusp, 2013.

VANSINA, Jan. Kingdoms of the Savanna. Madisson: University of Wisconsin Press, 1966.

VENÂNCIO, João Carlos. A economia de Luanda e hinterland no século XVIII. Lisboa: Editorial Estampa, 1996.

VRIES, Jan de. A economia da Europa numa época de crise. Lisboa: Dom Quixote, 1983.

WRIGLEY, Edward Anthony. Historia y poblacion: introducción a la demografia histórica. $2^{\mathrm{a}}$ edição. Barcelona: Critica, 1985.

\section{Fontes}

FONSECA, André Velho da. Relatório de todos os gastos que se fazem nos reinos de Angola e de Congo, assim de justiça e governo como da igreja e guerra (1612). Arquivos de Angola, vol. III, abril a junho de 1937, p. 19-21.

SILVA, Luís Lobo; SOUZA, João da Silva de; CABRAL, Hierônimo da Veiga. Relação por maior do Estado em que acha o Reino de Angola, suas províncias e conquistas, do número de gente de guerra e moradores e residentes desta cidade e seus presídios (...), 20/11/1684. AHU, Avulsos, Angola, cx. 13, doc. 1575.

CORRÊA. História de Angola, vol. 1 e 2. Lisboa: Editorial Ática Ltda, 1937 (1792).

TORRES, João C. F. Memórias contendo a biographia do vice-almirante Luiz da Motta Feo e Torres em A história dos governadores e capitães gerais de Angola, desde 1575 até 1825 e a Descripção geographica e política dos reinos de Angola e Benguela. Paris: Fantin Livreiro, 1825.

LIMA, José Joaquim Lopes de. Ensaios sobre a statistica das possessões portuguezas no Ultramar, livro III, de Angola e Benguella e suas dependências. Lisboa: Imprensa Nacional, 1846. 
Arquivo Histórico Ultramarino (AHU). Documentos avulsos de Angola, diversas caixas e documentos.

Arquivo Histórico do Tribunal de Contas (AHTC). Erário Régio (ER), cód. 4192.

\section{Sites com bancos de dados consultados}

ELTIS, David et al. Voyages: the trans-Atlantic slave trade database. Disponível em: http://slavevoyages.org/. Acesso em: 12/11/2012.

MATOS, Paulo et alli. Counting colonial populations. Disponível em: http://colonialpopulations.fcsh.unl.pt/. Acesso em: 14/04/2016.

Recebido: 31/10/2016 - Aprovado: 06/12/2017 